\title{
THE UNIVERSITY OF ADELAIDE
}

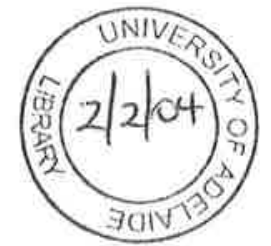

SEMESTER 1, 2002

\section{TOPIC OF THE DISSERTATION: INTRA-ASEAN ECONOMIC COOPERATION}

\author{
CONVENOR: DR FELIX PATRIKEEFF
}

\section{STUDENT: ENTEL DAJSMAILI}

\begin{abstract}
A Master's Paper Presented to the Political Science Department, as Partial Fulfillment for the Degree of Master of Arts in International Studies
\end{abstract}

DUE DATE: FRIDAY, $21^{\text {TH }}$ OF JUNE 2002 


\section{TABLE OF CONTENTS}

1. INTRODUCTION

2. ASEAN AND ECONOMIC REGIONALISM

- Periodization of Intra - ASEAN Economic Initiatives

\section{ECONOMIC COOPERATION}

- The Preferential Trading Arrangement

- ASEAN Industrial Projects

- ASEAN Industrial Complementation

- ASEAN Industrial Joint Ventures

- Lesson from the First Phase of Intra - ASEAN Economic Cooperation

\section{A TRANSITION TO ECONOMIC INTERGRATION}

- The Common Effective Preferential Treatment

- The Growth Triangles

- ASEAN Free Trade Area

- The Framework Agreement on Enhancing ASEAN Economic Cooperation

- The Future of the Second Phase in Intra - ASEAN Economic Cooperation

\section{CONCLUSION}

Appendices

Reference 
Appendices

1. Declaration of ASEAN Concord $\quad \ldots 65$

2. Joint Press Statement : The Twenty - Third Meeting of the ASEAN Economic Ministers

3. Framework Agreement on Enhancing ASEAN Economic Cooperation

4. Table A. 1 : Trade Balances of Selected ASEAN Countries

5. Table A.2 : Intra-ASEAN Trade : Amount of Trade with Other ASEAN States and Percentage of Total Trade

6. Initial Research Proposal 
Tables

1.Basic Indicators of the ASEAN States: 1995

2.ASEAN Trade, 1985 and 1990

3.Share of Intra - ASEAN Total Exports (\%)

4.ASEAN Industrial Projects

5.Basic Indicators for SIJORI Growth Triangle

A.1. Trade Balances of Selected ASEAN Countries

A.2. Intra - ASEAN Trade: Amount of Trade with Other ASEAN States and Percentage of Total Trade 


\begin{tabular}{|c|c|}
\hline AEM & ASEAN Economic Ministers Meeting \\
\hline AFTA & ASEAN Free Trade Area \\
\hline AIC & ASEAN Industrial Complementation \\
\hline AIJV(s) & ASEAN Industrial Joint Venture(s) \\
\hline $\mathrm{AIP}(\mathbf{s})$ & ASEAN Industrial Project(s) \\
\hline APEC & Asia Pacific Economic Cooperation \\
\hline ASEAN & Association of Southeast Asian Nations \\
\hline ASEAN - CCI & ASEAN Chambers of Commerce and Industry \\
\hline CEPT & Common Effective Preferential Treatment \\
\hline COFAB & Committee on Finance and Banking \\
\hline CAFAF & Committee on Food, Agriculture and Forestry \\
\hline COIME & Committee on Industry, Minerals and Energy \\
\hline COTAC & Committee on Transportation and Communications \\
\hline COTT & Committee on Trade and Tourism \\
\hline EAEC & East Asian Economic Caucus \\
\hline EAAG & East Asia Economic Group \\
\hline EC & European Community \\
\hline GATT & General Agreement of Tariffs and Trade \\
\hline NAFTA & North American Free Trade Agreement \\
\hline PTA(s) & Preferential Trading Agreement(s) \\
\hline SIJORI & Singapore - Johor - Riau (growth triangle) \\
\hline
\end{tabular}




\section{TOPIC: INTRA-ASEAN ECONOMIC COOPERATION}

\section{INTRODUCTION}

The Association of Southeast Asian Nations (ASEAN) was formed in 1967. Its original members were Indonesia, Malaysia, the Philippines, Singapore and Thailand. Brunei joined the Association shortly after its independence in 1984. Later, in an effort to get the ten states in Southeast Asia grouped in the Association, Vietnam was granted the membership in 1995, Myanmar and Laos in 1997 and Cambodia in 1999. ${ }^{1}$ The first two of ASEAN's seven objectives are:

i. To accelerate the economic growth, social progress and cultural development in the region through joint endeavours in the spirit of equality and partnership in order to strengthen the foundation for a prosperous and peaceful community of South - East Asia nation;

ii. To promote regional peace and stability through abiding respect for justice and the rule of law in the relationship among countries of the region and adherence of the principles of the United Nation's Charter;", ${ }^{2}$

Since its information, ASEAN has ventured into various fields of cooperation. The two main areas of cooperation after its inception were security and economic. Through regional cooperation, ASEAN has minimized manipulation and domination by the great powers. In 1975, Adam Malik, then Foreign Minister of Indonesia, stated that "ASEAN can be see as reflecting the growing political will of the nations of this region to take charge of their own future, to work out problems of their development, stability and security together and to prevent their region from continuing to remain the arena and the subject of major power and conflict." ${ }^{3}$

When ASEAN first ventured into economic cooperation, the major concern of the member states was the security issues in the region. The rationale of its economic cooperation at that time was to reduce the security threats that might arise had there not been any constructive engagement amongst the member states.

\footnotetext{
"The move toxards "AstEAN T0" was Turther taken closer to reality when, at the ASEAN Foreign Ministers Meeting in July 1996 (Indonesia), Laos and Cambodia submitted their applications to joint ASEAN in1997. Myanmar, which made her debut as an observed at the 1996 ASEAN Foreign Ministers, is expected to follow suit later.\& Lee Kuan Yew, From Third World to First: The Singapore Story 1965-2000, (HarperCollinsPublishers, $2000)$.

${ }^{2}$ Law and Practice under the GATT: ASEAN \& APEC, compiled and edited by Paul Davidson, (New York: Oceana Publications,

1996), p. 2.

3 Shee Poon Kim "A Decade of ASEAN: 1967 - 1977," in Asian Survey, Vol. 17, No. 8, Auguet 1977, p. 754
} 
This neo - Functional approach to regional integration (i.e., of having cooperation in one field in the hope that it will spill - over to other areas of cooperation) can be traced back to the early years of ASEAN. In a study of the ASEAN's first decade, Shee Poon Kim wrote, "[a] growing feeling of anxiety due to the deteriorating security situation and a desire to complete peacefully with the Indochinese states could be detected. This mood was reflected in the ASEAN leaders' attempts to accelerate economic development and to strengthen economic cooperation for fear that unless the Association showed inviability in the form of economic cohesiveness, it might be surpassed by the Indochinese states." ${ }^{.4}$ ASEAN's security preoccupation for the economic cooperation is reflected more clearly by Stuart Harris when he said, "ASEAN.... used economic cooperation as an instrument rather than an objective, seeing political benefits emerging from the presumed much less contentious process of economic cooperation and the enhanced economic interdependence that would follow."

Despite this belief, it took ASEAN almost nine years to come out with its economic plans. An obvious factor for this late take - off can be attributed to ASEAN leaders' lack of vision in the future direction of the association at that time. As the then Singaporean Foreign Minister Rajaratnam, speaking at the 1974 ASEAN Ministerial Meeting, rightly put it, "[y]ou may recollect at the first meeting in 1967 , when we had to draft our communiqué, it was a very difficult problem of trying to say nothing in about ten pages, which we did. Because at that time, we ourselves having launched ASEAN, were not quite sure where it was going or whether it was going anywhere at all." 6

Despite its passivity, ASEAN leaders had from time to time, before the 1976 Bali Summit, proposed certain measures of economic cooperation. The most notable among these proposals come from the then President of the Philippines in 1971. President Marcos “.... suggested that the 1970 s be declared 'the ASEAN Development Decade' and that ASEAN establish a limited free trade area in a selective commodity basis and a payments union within the ASEAN region," 7 To have suggested such a free trade area in 1971 was premature. The reservation of ASEAN member states was manifested in 1972, when, chairing the fifth Ministerial Meeting, the then Singaporean Prime Minister, Lee Kaun Yew "... gained the impression that ASEAN did not for the present aim at integrating a regional economy, It would, therefore, be unrealistic for ASEAN to propose programs and projects which did

\footnotetext{
4 Ibid., p, 762

5. Harris, Stuart, "The Economic Aspects of Security in the Asia / Pacific Region", in Iournal of Strategic Studies, 1995 Special Issue, (London, Frank Cass, 1995), p. 47.

6. Quoted in Frost, Frank, "Introduction: ASEAN Since 1967 - Origins, Evolution and Recent Development, "in

Alison Broinowski, ed., ASEAN into the 1990s, (New York: St. Martin's Press, 1990), p. 5.

7. Quoted in Law and Practice under the GATT, op. cit.
} 
not fit into and assist in the consolidation of the respective economic development plans of the five countries." 8

The agreement to venture into economic cooperation finally came in 1976, the year ASEAN held its first summit meeting. The meeting agreed to embark on several measures of economic cooperation, particularly in large - scale industrial projects and trade liberalization. These measures, however, had manu problems; ranging from the lack of political will, to the weakness in regional planning. Intra - ASEAN economic collaboration entered a new phase in 1991 when ASEAN agreed to partake in economic integration with the decision to achieve an ASEAN Free Trade Area (AFTA) in 15 years time.

Economic collaboration in ASEAN can be categorized into two phases. The first phase of economic cooperation took place between 1976 - 1991. During this first phases, ASEAN experimented cooperation in trade and industry at the regional level. In terms of trade cooperation, ASEAN agreed to implement the Preferential Trading Arrangement (PTA) as the vehicle to liberalize trade relations amongst the member states. ASEAN also ventured into large - scale industrialization through the mechanisms of ASEAN Industrial Projects (AIPs), ASEAN Industrial Complementation (AIC) and ASEAN Industrial Joint Ventures (AIVJs). The second phase began in 1991 when ASEAN economic ministers outlined several other programs to consolidate the existing cooperation mechanisms. The ministers proposed the establishment of ASEAN Free Trade Area (AFTA); the adoption of the Common Effective Preferential Treatment (CEPT) as the tool for achieving AFTA; the formalization of growth triangles; and the possibility of signing a treaty on economic cooperation. The main distinction between the two phases lies in the question of economic integration: whereas before 1991, the characteristic of economic cooperation in ASEAN was loose, the projects endorsed at the $23^{\text {rd }}$ ASEAN Economic Ministers Meeting (AEM) aimed at achieving a truly liberalized marked in a fifteen years timeframe.

The first phase of economic cooperation in ASEAN (1976 - 1991) had been plagued by several problems. ASEAN's industrial cooperation was designed to be flexible for the participation of both the governments and private sectors. The AIPs were participated only by the governments, while the private sectors were invited to participate with the governments in the AIC. The private sectors are also encouraged to participate in the AIJVs through collaboration with other private sectors inside and outside the region. However, ASEAN was not prepared to seriously implement these programs since 8. Ibid. p. 20. 
the member states' focus was directed more towards developing their own domestic economies. This was the reason why industrial projects such as the AIPs, AIC and AIJVs could not achieve satisfactory results, in the area of trade, the PTA could not function effectively as the tool for liberalization because trade relationship amongst the members states were minimal and they had to also protect their own products. These problems, nonetheless, did not discourage ASEAN from enhancing its economic collaboration. This is manifested by ASEAN's decision to pursue new economic programs as proposed by the $23^{\text {rd }}$ AEM.

The $23^{\text {rd }}$ ASEAN Economic Ministers Meeting in 1991, which paved the way for the second phase of ASEAN's economic collaboration, had adopted an integration measure be agreeing to achieve and ASEAN Free Trade Area (AFTA) by 2008. To facilitate the achievement of AFTA, ASEAN agreed to adopt the Common Effective Preferential Treatment (CEPT) as a tariff - cutting mechanism. ASEAN has shown its maturity by not attempting to create new industrial projects in this new package of economic cooperation. ${ }^{9}$ The decision not to pursue any new industrial projects was very wise considering the meagre success experienced by ASEAN with such projects in the past. The significance of the $23^{\text {nd }} \mathrm{AEM}$ is that the member states agreed to move forward with new economic programs despite its relative failure in its first phase of economic cooperation. The reason of this transformation is therefore not purely economic. It can be understood through ASEAN's efforts of strengthen its institution - building and as its reaction towards economic regionalism elsewhere.

A new perspective o intra - ASEAN economic cooperation is, therefore, in order. It will examine why, despite past failures, ASEAN still wants to continue its economic cooperation in a more integrative manner. Thus, this perspective will analyse the paradox of a regional organization, with unsuccessful experience in economic cooperation, trying to intensify its collaboration to a degree which resembles economic integration. This research will examine the rationale behind transformation and analyse the various kinds of economic cooperation adopted by ASEAN.

The thesis of this paper is that ASEAN's moves toward economic regionalism is motivated by its realization to strengthen its institution - building, and its need to react against external trends in regionalism. The paper is organized as follows: section two will consider the theoretical aspects of economic regionalism, their application to ASEAN, the reasons behind the recent transformation in

\footnotetext{
9. Although ASEAN did not adopt new industrial projects at the 23rd AEM, it endorsed eight new products to be placed under the AIJV approval list. See appendix 2, p.....
} 
economic cooperation adopted by ASEAN, and the periodization of ASEAN economic cooperation with 1976 as the beginning of economic cooperation, and 1991 as the starting point of economic integration. Section three will examine the measures taken by ASEAN in economic cooperation, their successes and failures, and lessons to be learmt from such endeavours. Section four will explore the nature of economic integration in ASEAN, with a major emphasis on ASEAN Free Trade Area (AFTA). The final section will conclude the argument of this paper, pointing to the extent of integration in ASEAN thus far, and the challenges and opportunities in intra - ASEAN economic cooperation. 


\section{ASEAN AND ECONOMIC REGIONALISM}

As a regional organization, ASEAN started to promote common economic programs since its first summit in 1976. The summit provided for some measures to be taken by ASEAN to enhance economic cooperation amongst its members. This cooperation, defined in broad terms, was the agreement of ASEAN member states to venture into several mechanisms that can promote economic growth in the region. Economic cooperation denotes "concerted actions aimed at lessening discrimination in certain areas of common concern." ${ }^{.10}$ In this regard, the various measures pursued by ASEAN had the objectives of lessening discrimination through joint efforts by the member states Some of the examples of ASEAN economic cooperation, as envisioned in the 1976 Bali Summit, are the Preferential Trading Arrangement (PTA), the ASEAN Industrial Project (AIP), the ASEAN Industrial Complementation (AIC), and the ASEAN Industrial Joint Venture (AIJV).

As ASEAN progressed, it then saw the necessity to improve its cooperation. From a loose partnership, it agreed to venture into a deeper one, with the attempt at integrating its economy through a free trade area by 2008 . When the ASEAN economic ministers proposed the establishment of ASEAN Free Trade Area in 1991, it can be seen as the turning point of ASEAN into economic integration. Economic integration, referred here, is defined as "various measures leading to a suppression of discrimination between economic units of national states and (that) the resulting forms of economic integration can be characterized by the absence of discrimination in various areas." 11 ASEAN envisions a region of free trade where products can move freely within the region through this process of integration.

It should be noted, however, that economic integration in ASEAN is still a process, and not yet an outcome. It is pale in comparison with the more advanced integration schemes adopted by the European Community (EC) and North American Free Trade Agreement (NAFTA). The European Community comprises of four different forms of integration described by Peter Robson, namely; "free trade area, customs union, common market and economic union." ${ }^{\prime 12}$ By contrast, ASEAN is only at the early stage of forming a free trade area, a stage where many controversies are still unresolved. It does not attempt at achieving the other three forms of integration adopted by the EC

\footnotetext{
10. Langhammer, Rolf, "ASEAN Economic Cooperation: A Stock - Taking from the Political Economy Point of View", in ASEAN Economic Bulletin, Vol. 8, No. 2, November 1991, p. 184n.

11. Balassa, Bela, "Toward A Theory of Economic Integration", in Miguel S, Wionczek, ed., Latin American Economic Integration: Experiences and Prospects, quoted in Rajendran, M., ASEAN's Foreign Ralations: A Shift to Collective Actions, (Kuala Lumpur: Arenabuku, 1985), p.1.

12 Robson, Peter, The Economics of International Integration, (London: Allen and Unwin, 1980), p. 2.
} 
In comparison with NAFTA, the provisions in the ASEAN Free Trade Area (AFTA) are still being negotiated by the member states. There is no legally - binding document signed to facilitate AFTA, instead a mechanism called the Common Effective Preferential Treatment (CEPT) was introduced to streamline the process of tariff - cutting. In NAFTA, however, a binding agreement was signed by the contracting parties to facilitate the process of its free trade area.

The member states of AFTA and NAFTA are also members of the Asia Pacific Economic Cooperation (APEC). The APEC forum, which also includes other countries in the Pacific Rim, declares its commitment toward 'open regionalism'. Open regionalism, in the context of APEC, is “...essentially aimed at regional economic cooperation by Pacific Rim countries for reduction of barriers to trade, both official, such as tariffs and non - tariff barriers, and others such as transport and transaction costs, and in this and other ways at the maintenance of an open world trading system in the pure GATT spirit."13 In other words, the APEC process can be understood as an effort to promote closer relationship amongst the member states while maintaining a positive outward orientation in trade. APEC's rationale is to "... achieve regional agreement on trade issues which could not yet be resolved at the global level."14

There is also another categorization of economic integration provided by J. Tinbergen, namely 'positive' and 'negative' integration. According to Tinbergen, positive integration "concerned with the modification of existing instruments and institutions and the creation of the new ones, for the purpose of enabling the market to function effectively and also to promote other broader policy objectives in the union", while negative integration describes "those agents of integration which involve the removal of discrimination and restrictions on movement, such as arise in the process of trade leberalization."15 In theory, ASEAN is adopting the negative integration process. This is because ASEAN does not create new institutions of facilitate its integration, as understood in the process of positive integration, rather it places the new mechanisms for integration under the existing organizational structure. Moreover, ASEAN strives to remove discrimination and restrictions that would hinder trade liberalization.

ASEAN's transformation in economic cooperation can be understood in terms of its efforts to strengthen its institution - building and as a reaction to external trends in the East Asian region and elsewhere. ASEAN has to respond to the rapid changes in the region, especially in the economic field.

\footnotetext{
13. Arndt, H. W., "Anatomy of Regionalism", in Garnaut, Ross and Peter Drysdale, ed., Asia Pacific Regionalism: Readings in International Economic Relations, (New South Wales: HarperEducational, 1994), p. 90.

14 Bergsten, C. Fred, "APEC and the World Economy: A Force for Worldwide Liberalization", in ibid. p. 218.

15. Quoted in Robson, op. cit., P.1.
} 
ASEAN's moves towards economic integration is puzzling considering the fact that it was not successful in the economic cooperation it attempted since 1976. An analysis of why ASEAN moves toward integration measures in spite of its failure in the first phase of economic cooperation, which is the subject of this research, is therefore required. Economic cooperation was basically a secondary objective before 1991, since the foremost concern was the security question, where there were perceived threats from the Soviet Union, China and communist Indochina, coupled with existing territorial claims amongst the ASEAN member states. However, these threats have been reduced with the dissolution of the Soviet Union, the opening of China's market and political reform in Indochina. In the meantime, many ASEAN states are experiencing unprecedented growth in their economic. With a cumulative average annual growth rate of more than 7 percent, ASEAN countries are having one of the highest growth rates in the world. (see Table 1).

Table 1: Basic Indicators of the ASEAN States: 1995

\begin{tabular}{|c|c|c|c|c|c|c|c|}
\hline Indicators & Singapore & Malaysia & Thailand & Philippines & Indonesia & Brunei & Vietnam \\
\hline $\begin{array}{l}\text { Population } \\
\text { (Mil) }\end{array}$ & 3.1 & 20.6 & 61.2 & 68.9 & 197.6 & 0.3 & 75.9 \\
\hline $\begin{array}{c}\text { Area } \\
\left(1000 \mathrm{~km}^{2}\right)\end{array}$ & 0.7 & 330 & 514 & 300 & 1,919 & 5.8 & 330 \\
\hline $\begin{array}{l}\text { GDP/Capita } \\
\text { (US \$) }\end{array}$ & 23,565 & 9,470 & 7,535 & 2,935 & 3,705 & 21,065 & 1,263 \\
\hline $\begin{array}{c}\text { GDP } \\
\text { Change (\%) }\end{array}$ & 8.3 & 9.2 & 8.6 & 5.6 & 7.2 & 1.8 & 9.5 \\
\hline $\begin{array}{l}\text { Inflation } \\
\text { (CPI) }\end{array}$ & 1.7 & 3.4 & 5.8 & 8.1 & 9.4 & 24 & 4.6 \\
\hline $\begin{array}{c}\text { Adult } \\
\text { Literacy }(\%)\end{array}$ & 91.6 & 89.3 & 93.8 & 94 & 84.4 & 89.2 & 91.9 \\
\hline $\begin{array}{c}\text { Life } \\
\text { Expectancy }\end{array}$ & 76 & 72 & 69 & 67 & 63 & 75 & 67 \\
\hline
\end{tabular}

Source: International Monetary Fund, World Economic Outlook: A Survey by the Staff of the International Monetary Fund, (Washington, D.C.: IMF, 1996), Far Eastern Economic Review, April 4, 1996, pp. 66 - 67, Asiaweek, April 4, 1996. 
Despite this unprecedented annual growth rate, the total intra - ASEAN trade was minimal. As table 2 shows, the direction of ASEAN trade was channelled more towards other regions. For example, ASEAN trade towards the East Asian countries accounted for the most percentage (34.4\%), while its trade to the European Community recorded the highest percentage growth between 1985 and 1990.

Table 2: ASEAN Trade, 1985 and 1990

\begin{tabular}{|c|c|c|c|}
\hline & 1985 & 1990 & Growth (\%) \\
\hline \multicolumn{4}{|l|}{ Breakdown by region (\%) } \\
\hline Intra-ASEAN & 19.7 & 17.7 & 14.8 \\
\hline East Asia & 33.8 & 34.4 & 17.7 \\
\hline $\mathrm{EC}$ & 11.5 & 4.8 & 23.4 \\
\hline Rest of the World & 16.2 & 15 & 15.5 \\
\hline Total & 100 & 100 & 17.3 \\
\hline US $\$$ billions & 135.5 & 301.6 & \\
\hline
\end{tabular}

Source: Kumar, Sree, "Policy Issues and the Formation of the ASEAN Free Trade Area", in Naya, Seiji, and Pearl Imada, ed., AFTA: The Way Ahead, (Singapore: Institute of Southeast Asian Studies, 1992), p. 73.

This small volume of intra ASEAN trade is one of the reasons for the failure of the economic programs adopted by ASEAN in its first phase of economic cooperation. Nevertheless, this statistics did not bother the ASEAN states in planning for newer economic collaboration mechanisms. This is because ASEAN is motivated to strengthen its institution - building in light of external trends in economic regionalism.

The institution - building efforts in ASEAN were intensified at the Fourth ASEAN Summit in 1992. up to this point, ASEAN was regarded as being successful in the political sphere, especially its ability to survive communist threats and the major powers struggle in the region. A symbolic gesture of institution - building in ASEAN was evidenced in the decision made at the Fourth ASEAN Summit meeting in 1992 to create the post of the Secretary General of ASEAN, with a ministerial status. Before the summit, there was a post of the Secretary General of the 'ASEAN Secretariat' whose main executive function was merely to supervise the daily workings of the Secretariat. The decision helped contribute to the strengthening of the multilateral ties amongst the ASEAN member states. The intensification of multilateral relations in ASEAN was also enhanced with the decision to institutionalise ASEAN Summit meeting at the interval of three years beginning in 1992. Before this decision, the ASEAN Summit was called only ' as and when the need arises'. ${ }^{16}$

The organizational change in ASEAN which boosted the institution - building efforts was 
basically preceded by the agreement of its economic ministers in the $23^{\text {rd }}$ ASEAN Economic Ministers Meeting (AEM) in 1991. The ministers agreed that it was high time for ASEAN to strengthen its ties through additional economic cooperation measures. A marked change of direction can be observed in the $23^{\text {rd }}$ AEM where decisions were made to elevate ASEAN's economic cooperation through trade mechanisms, namely; NAFTA, the CEPT and the growth triangles. The $23^{\text {rd }}$ AEM did not propose new vehicles for industrial cooperation which were ineffective in the past. In this regard, institution building in ASEAN was carefully designed so that failed economic mechanisms could be dropped to make way for more beneficial economic vehicles.

ASEAN was also reacting against other regional arrangements being set up elsewhere. ASEAN sees the EC and NAFTA as two economic groups which can affect its trade to the two regions. In light of anticipated trade loss to both regions, ASEAN's reaction was to intensify its intra - regional trade through AFTA, the CEPT and the growth triangles. ASEAN's scepticism towards other regional arrangements is also indicated by the Malaysian prime minister's proposal to create the East Asian Economic Group (EAEG - later, East Asian Economic Caucus [EAEC] ), ${ }^{17}$ and Singapore senior statesman Lee Kuan Yew's persistent defence of Asian values as being unique from the Western viewpoint.

There are other explanations in the rationale for ASEAN to start its own integration measures. John Ravenhill identified four reasons why, despite the many ineffective cooperation schemes pursued by the organization, it still opted for greater integrative efforts. They are:

"(1) the search for a new rational for ASEAN

(2) the changing international context, particularly the growth of regionalism elsewhere in the world economy and concern that the Uruguay Round would not reach a successful conclusion;

(3) fear of investment diversion particularly to China; and

(4) the growing complementarity of the ASEAN economies, a reflection of structural changes in 1980s."18 (numbers added)

\footnotetext{
17. Prime Minister Mahathir Mohamad first proposed the creation of East Asian Economic Group (EAEG) in 1991. His main idea was to bring logether the East Asian ecoromies into one group so that they can act in one voice in multilateral economic negotiations. This idea was criticized, particularly by the West, as an attempt to form an economic bloc. The mixed reactions from East Asian countries also made this proposal unsuccessful, especially when Japan gave a cold response to the idea. ASEAN then took this proposal as its project, changing its name to become East Asian Economic Caucus (EAEC). The approach was also changed to become only a consultative forum within APEC, as proposed by Indonesia.

18.. Ravenhill, John, "Economic Cooperation in Southeast Asia: Changing Incentives", in Asian Survey, Vol. 35, No. 9, September 1995, pp. 583-4.
} 
These four reasons can be further simplified into two categories; the first and the last as institution - building measures, while the second and the third as reactions towards economic environment outside the region.

Ravenhill's first category of institution - building touches upon the need for ASEAN to espouse a new rationale for its existence. The agreements on economic initiatives achieved in the 1991 AEM and the $4^{\text {th }}$ ASEAN Summit in Singapore (1992) indicated the ASEAN's acknowledgment of the need to embrace a new raison d'êntre. It was evidenced by then that the Cold War threats had been removed with the collapse of the Soviet Union and through the substantial progress of ending the Cambodian conflict. Therefore, the new economic arrangements adopted by ASEAN served as an important symbolic purpose for ASEAN as an organization. As ASEAN can no longer rely solely in perceived security threats as the raison d'êntre of its existence, the move toward greater cooperation serves as the motivation for ASEAN to maintain the relevance of its existence.

As regards to the ASEAN economies' structural change, Ravenhill's fourth reason, "the high rates of economic growth of the late 1980s, which led to some ASEAN economies being accorded the title of 'next - tier NICs' (newly - industrialized countries), boosted the confidence of ASEAN leaders in the ability of domestic industries to withstand the competitive pressures that would arise from freer trade. ${ }^{.19}$ This structural change, furthermore, provided ASEAN with the much - needed push towards institution - building. Seen from this angle, the integration process in ASEAN is 'natural', a function of economic growth in the region.

Ravenhill's second reason, ASEAN's reaction towards other regional integration elsewhere, finds its rationale in the changing tends in international economic arrangements. This line of argument is justified by an econometric study which estimated that "ASEAN will lose $4 \%$ of the value of its 1988 exports to North America from the trade diverting effects of NAFTA, and $8 \%$ of the value of its exports to the European market from trade diversion caused by the conclusion of the Single European Market." ${ }^{20}$ Although the loss was still in a single digit percentage toward each region, ASEAN appeared to be unwilling to take any chance from such losses.

Finally, Ravenhill has rightly pointed out to the fact that ASEAN's move towards economic integration was also influenced by the fear of investment diversion. The most salient threat to the region was the concern about "investment diversion to China, both by subsidiaries of American,

19. Ibid. p. 855

20. Ibid. .854 
European and Northeast Asian transnationals and by Chinese business communities in Southeast Asia." ${ }^{21}$ With this relative opening of the huge Chinese market, ASEAN attempted to create a more attractive home for foreign investment which it hopes can be achieved through concerted economic efforts.

Economic regionalism in ASEAN, then, is an attempt to focus on economic integration through a free trade area. The characteristics of this integration are very loose, negative and differ from those of NAFTA and EC. The transformation from a loose cooperation $(1976$ - 1991) to economic integration (1991 onwards) in ASEAN is not a function of past successes in its efforts. This is because ASEAN failed to achieve impressive outcome in the economic cooperation efforts which began since 1976. Rather, this process of integration is triggered by the motivation of institution - building and the need to react to external regional economic trends. In this regard, ASEAN considers economic integration to be a tool for strengthening its organization while preparing itself to stand against other regional economic trends that may jeopardize its member states' economies. The whole process of intra - ASEAN economic cooperation can be further analysed from two distinctive phases: economic cooperation since 1976; and economic integration from 1991 onwards.

\section{Periodization of Intra - ASEAN Economic Initiatives}

There are two distinctive phases in intra - ASEAN economic initiatives. The first phase, economic cooperation, began in 1976 while the second phase, a transition to economic integration, began in late 1991. This periodization focuses on the institutionalisation of economic cooperation in ASEAN. While institutionalisation during the early years was generated mainly by security cooperation, ASEAN has given economic cooperation a more serious approach after 1991 to maintain its relevance as a regional organization. This periodization, therefore, considers the agreement for embarking on the economic projects as the starting point of each period. It does not conceive the achievement of each projects as the periods in economic cooperation in the region. The rational behind this periodization is to understand the dynamics of the decision - making process in ASEAN and the visions of the ASEAN leaders in strengthening their economic cooperation.

A comprehensive periodization on the progress of ASEAN is given by Frank Frost. Frost, while writing in 1980, identified three periods (1967 - 1975, 1975 - 1976, 1977 onward) as significant dates in the evolution of the organization. ${ }^{22}$

21. Ihid.

22. Frost, in Alison Broinowski, ed. cit., pp. 1 - 13. 
According to Frost, the early years of 1967 - 1975 were insignificant in that the member countries were not quite sure on the direction they wanted to go. Not much progress was achieved during this period and the organization was practically run by the Foreign Ministers who met once a year.

Frost then went on to characterize 1975 - 1976 as the turning point in ASEAN. The year 1975 was significant because it was the year the non Communist regime in Cambodia and South Vietnam collapsed, and ASEAN had to response to this phenomenon in unison. As for 1976, it was historical fro ASEAN since the first Heads of Government Meeting was held in Bali, Indonesia. It was here that two important declarations were signed, namely; the ASEAN Concord, and the Treaty of Amity and Cooperation. Whereas the latter concerned with security arrangement in the region, the former was the documented agreement reached by the heads of government in their meeting. The ASEAN Concord, among others, outlined four areas of economic cooperation: "cooperation on basic commodities, particularly food and energy; cooperation in the established of large - scale ASEAN industrial projects; cooperation in intra - regional trade liberalization; and joint approaches to international commodity problems and other world economic problems. ${ }^{\text {"23 }}$ Frost's analysis of ASEAN;s development since 1977 provides explanation and critique of the various ASEAN's efforts since the Bali Summit in various areas of collaboration. Frost's analysis of ASEAN development was wide - ranging, taking into account the development of ASEAN and the Southeast Asian region in political, economic and security issues. In the economic sphere, the cooperation began in 1976.

Economic cooperation, then, is considered to begin with the endorsement of ASEAN's heads of government to participate in the endeavours in 1976 . The rationale for this periodization is that in 1976, ASEAN leaders agreed for the first time to attempt collectively at participating in economic projects through the regional organization. In other words, the economic cooperation measures taken by ASEAN in the ensuing years were dependent upon the agreement reached in the 1976 Bali Summit. Among the projects discussed at the first Summit were the Preferential Trading Arrangements (PTAs), the ASEAN Industrial Projects (AIPs), ASEAN Industrial Joint Ventures (AIJVs) and ASEAN Industrial Complementation (AIC). Those projects became the cornerstone of intra - ASEAN economic cooperation with its different stories of relative success and failure. With the instrument of various economic committees and the institution of ASEAN Economic Ministers' Meeting (AEM), the 23. Ibid. p. 9. For the full text of the ASEAN Concord, see Appendix 1. 
economic projects were further reviewed and altered, until ASEAN agreed on some new programs following the $23^{\text {rd }}$ ASEAN Economic Ministers' meeting in October 1991. These programs reflected a different characteristics in comparison with the ones it had before.

The $23^{\text {rd }} \mathrm{AEM}$ was held in Kuala Lumpur on October 7 and 8 , 1991. It emphasized "the need for ASEAN to adopt timely and effective measures to strengthen its intra - and extra - ASEAN economic cooperation." ${ }^{24}$ It was here that the economic ministers discussed and agreed on new initiatives in economic relations, namely: the Common Effective Preferential Treatment (CEPT); the 'Growth Triangle Concept'; and the establishment of an ASEAN Free Trade Area (AFTA). The meeting also agreed to change the name of the controversial AEST Asian Economic Group (EAEG) to the East Asian Economic Caucus (EAEC), and adopted it to be an ASEAN project. The meeting also discussed the possibility of "an ASEAN Treaty of Economic Cooperation which could be signed by the ASEAN heads of government in the ASEAN Summit the following year."25 However, it was decided that a treaty was not necessary; instead "a framework for agreement, which is a less legally binding document, was chosen." 26 The statement issued at the end of the AEM states that "[t]he Ministers decided to treat the new initiatives as part and parcel of an integrated package towards the creation of a truly liberalized ASEAN market."27

The year 1991, then, was another significant period in ASEAN economic cooperation. It was the year ASEAN economic ministers agreed to venture into economic integration, through a free trade area, which is to be achieved by 2008 . The recommendations put forward in the $23^{\text {rd }}$ AEM were then endorsed by the ASEAN heads of government in the $4^{\text {th }}$ ASEAN Summit meeting in Singapore the following year (1992). Although the formalization of these mechanisms were endorsed in 1992, ASEAN economic ministers had extensively discussed their possibility to become part and parcel of its collaborative efforts during the $23^{\text {rd }}$ AEM in 1991. Therefore, the $23^{\text {rd }}$ ASEAN Economic Ministers Meeting was significant in paving the way to such transformation. It shows that ASEAN has strengthened its organizational structure to the extent that the AEM could contribute to the future direction of ASEAN. The $23^{\text {rd }}$ AEM, therefore, serves as the turning point of ASEAN economic cooperation. It was a manifestation of ASEAN members states' commitment to tighten the loose economic cooperation they had before and to further enhance their cooperation institutions.

24. The Xinhua General Overseas News Service, October 8, 1991. For the full text of the "Joint Press Statement of the 23rd Meeting of the ASEAN Economic Ministers, Kuala Lumpur, Malaysia, 7-8 October 1991", see Appendix 2.

25 lbid.

26 Pangestu, Mari, Hadi Soesastro and Mubariq Ahmad, "A New Look at Intra - ASEAN Economic Cooperation," In ASEAN

Economic Bulletin, Vo1. 8, No. 3, March 1992, p. 347. For the full text of "Framework Agreement on Fnhancing ASEAN Economic Cooperation", see Appendix 3.

27 The Xinhua Overseas News Service, October 8, 1991. 


\section{ECONOMIC COOPERATION}

Economic cooperation in ASEAN began in 1976. The ASEAN Concord, also known as the Bali Declaration in 1976, issued after the very first ASEAN Summit meeting, mentioned four types of economic cooperation: "cooperation in basic commodities, particularly food and energy; cooperation in the establishment of large - scale ASEAN industrial projects; cooperation in intra - regional trade liberalization; and joint approaches to international commodities problems and other world economic problems. ${ }^{.28}$ Of these projects, the cooperation in large - scale industrial projects and intra - regional trade liberalization were given more emphasis by ASEAN. Furthermore, ASEAN has made some substantial progress in these two areas.

There are three programs in large - scale industrial projects, namely; the ASEAN Industrial Project (AIP), ASEAN Industrial Complementation (AIC), and ASEAN Industrial Joint Venture (AIJV). In addition, the regional trade liberalization was facilitated by the Preferential Trading Arrangernent (PTA). These four projects originated from the recommendations by a United Nations' Study Group commissioned by the ASEAN foreign ministers in 1969. The main objectives of the recommendations was to "promote import - substitution on a regional scale, in which regional - wide industrial planning would provide some compensation for the expected imbalance in gains from liberalization of intra - regional trade. ${ }^{.29}$ This idea was indeed in lieu with the spirit of the time where development countries were urged to adopt an import - substitution strategy. However, when this experiment was done at the regional level, the result were not so impressive since the member states had to also develop their own industries.

The lack of progress in the first phase of ASEAN economic cooperation can be attributed to several factors, which mostly linked to political will and weak organizational structure. Ravenhill observed that "[n]ational jealousies over competing plans for import substituting industries, poor project preparation, and excessive bureaucratisation have stymied ASEAN's various efforts at industrial cooperation." ${ }^{30}$ In short, competing national interests that could not be harmonized were the major stumbling block. In addition, ASEAN's organizational structure was very weak as a consequence for the lack of institution - building efforts. No real decision - making power was given to the organization's secretariat, and there "have been excessive reliance on state planning especially as the

\footnotetext{
28. Frost, in Broinowski, ed., op. cit. p. 9.

29. Ravenhill, op. cit., p. 851

30. Ibid. p. 853
} 
bureaucratic infrastructure necessary for such a strategy was very weak and divided, the common Secretariat being little more than a 'mailbox'.,"31

Another major hindrance in this cooperation was the issue of trade policy. Is trade policy a responsibility of a supranational body like ASEAN? From the political economy perspective, as Langhammer argued, trade policy should be the responsibility of the national government. It can be transferred to the supranational authority when this qualification is met: "[t]o qualify trade policy as a supranational or regional task, one would expect a sizable share of intra - regional trade in total trade of member countries as this would indicate a certain degree of trade policy interdepence". ${ }^{32}$ However, this sizable share of intra - regional trade was lacking in ASEAN, as Table 3 shows. ${ }^{33}$

Table 3: share of Intra-ASEAN Total Export (\%)

\begin{tabular}{ccccccc}
1967 & 1970 & 1975 & 1980 & 1985 & 1990 & 1994 \\
\hline 20.9 & 21.4 & 17.2 & 17.9 & 19.7 & 17.7 & 20.8
\end{tabular}

Source: John Ravenhill, "Economic Cooperation in Southeast Asia", in Asian Survey Vol. 35, No. 9, September 1995, p. 851, and Sree Kumar, "Policy Issues and the Formation of the ASEAN Free Trade Area", in Seiji Naya and Pearl Imada, ed., AFTA The Way Ahead, (Singapore: Institute of Southeast Asian Studies, 1992), p. 73.

The table shows that total intra - ASEAN trade between 1975 and 1990 was smaller than the years before 1975 , i.e., the period before the economic cooperation measures were taken. The unimpressive outcomes of ASEAN's cooperation in trade can be attributed largely to this small size of intra ASEAN trade volumes. This, and other problems, will be addressed in the following sub - sections which are going to discuss the projects and programs carried out in the first phase of economic cooperation in ASEAN.

\section{The Preferential Trading Arrangements}

The agreement on ASEAN Preferential Trading Arrangement (PTA) was signed in Manila on February 24, 1977. the PTA agreement aimed at encouraging "greater intra - regional trade through the use of long - term quality contracts, preferential terms for financing imports, preferential treatment of imports by government agencies, preferential tariff rates, and liberalization of non - tariff barriers to regional trade. ${ }^{34}$ Under these arrangements, the member states were to grant trade preferences to one

31. Blomqvist, Hans C., "ASEAN as a Model for Third World Regional Economic Cooperation?", in ASEAN Economic Bulletin, Vol. 10, No. 1, July 1993, p. 57.

32 Langhammer, op. cit. p, 142.

33. See also Table 2, p. 14. For a detailed, country - by - country share of total intra - ASEAN trade, see Table A.2, Appendix 5 .

34. Tan, Gerald, "ASEAN Preferential Trading Arrangements: An Overview;" in Sandhu, K.S., Sharon Siddique, et. al., The ASEAN

Reader, (Singapore: Institute of Southeast Asian Studies, 1992). 
another on a selective basis. The member states were to lower their tariffs on trade items as agreed beforehand through the PTA lists. The instruments to be used for granting such preferences were: long term quality contracts; purchase finance support at preferential interest rates; preference in the procurement by government entities; extension of tariff preferences; liberalization of non - tariff measures on a preferential basis; and other measures. These preferential arrangements were to apply to basic commodities, particularly rice and crude oil; products of ASEAN Industrial Projects; products for the expansion of intra - ASEAN trade; and other products of interest to the contracting states.

The main issue surrounding the PTA was that it was not extensively used. Mari Pangestu, et. Al., attributed the low utilization rates of the PTA, from 1977 to 1987 , to the following implementation problems: "inclusion of irrelevant or un - traded items; too detailed disaggregation; tariff preferences on zero tariff items; non - automatic acceptance of product based on proof of origin and ASEAN content of the product; and long exclusion lists comprising the relevant products." ${ }^{\text {"35 }}$ At the Manila Summit (1987), several improvements of the PTA were made, in which the agreement stated: "ASEAN shall adopt and carry out a package of measures for the improvement of the PTA. Such measures shall include the progressive reduction in the number of items in the member countries' exclusion lists and the deepening of the margin of preference for items currently in the PTA. ASEAN shall also relax the ASEAN - content requirement in the Rules of Origin on a case - by - case basis."36 The ensuing discussion on these improvements agreed that "each member states should reduce the items on its exclusion list such that by 1992 , the items do not amount to more than 10 precent of the number of items traded by each nation and the value should exceed 50 percent of intra - ASEAN trade. ${ }^{37}$

As it turned out later, however, the PTA had only been able to produce negligible results. Langhammer identifies several reason for this meagre success, namely; "insufficient product coverage and depth of tariff cuts, the insignificance of tariff barriers relative to non - tariff barriers, and the possibility of tariff redundancy." ${ }^{38}$ Despite this failure, ASEAN has consistently attempted to improve this mechanism where structural changes and procedures for the inclusion of new items to the PTA list have been updated annually. ${ }^{39}$ It should also be noted that constant updating of the PTA has served as the basic framework of another preferential trading arrangement, the Common Effective Preferential Treatment (CEPT), to be discussed later in this paper.

35, Pangestu, et. al., op. cit., p. 335.

36. "The Manila Declaration," in Broinowski, ed., op.cit. p. 243, (Appendix A).

37. Pangestu, et. al., op. cit., p. 336.

38. Langhammer, op. cite p. 142.

39. Pangestu, et. al., op. cit., p. 336. 


\section{ASEAN Industrial Projects}

The ASEAN Industrial Projects (AIPs) began in1980. The idea of having the AIPs was discussed and endorsed at the Bali Summit of 1976. its origin can be traced back to the recommendations made by a United Nations' Study Group in 1972. The report listed eleven industries considered suitable "for cooperation development by the ASEAN countries, either alone or in cooperation with Cambodia, Laos, Vietnam, South Korea, and Sri Lanka." ${ }^{40}$ The study urged a package - deal approach to distributing the projects among the various countries. This means that a group of projects would not be allocated individually to each country; rather they should be assigned simultaneously to a group of countries for reason of fairness.

As regards to the projects, the ASEAN heads of government, in the Declaration of ASEAN Concord of 1976 declared that:

"(2) Industrial Cooperation

(i) Member states shall cooperate to establish large - scale ASEAN industrial plants, particularly to meet regional requirements of essential commodities.

(ii) Priority shall be given to projects which utilize the available materials in the member states, contribute to the increase of food production, increase foreign exchange and create employement."

Having agreed to adopt this project, the ASEAN economic ministers who met after the summit selected the allocated these five projects:

\section{TABLE 4: ASEAN Industrial Projects}

\begin{tabular}{ll}
\hline Country & Projects \\
\hline Indonesia & urea plants \\
Malaysia & urea plants \\
The Philippines & superphosphates \\
Singapore & diesel engine \\
Thailand & rack salt/soda ash
\end{tabular}

Source: A Business International Asian Research Report, ASEAN: Challenges of An Integrating Market. (Hong Kong: Business International Asia / Pacific L.td., 1979), p. 69

The cooperation nature of this project was such that every member states was to invest in all the projects, with the host state providing $60 \%$ equity of the total investment. However, the $10 \%$ equity to be provided by the other four states did materialize even at the beginning stage.

40. A Business International Asian Research Report, ASEAN: Challenges of An Integrating Market, (Hong Kong: Business International Asia / Pacific Ltd., 1979), p. 69.

41. Declaration of ASEAN Concord 1976, heading B. Economic, no. 2, in Law and Practice under the GATT, op. cit. See also Appendix 1. 
In the urea project, Singapore wanted to withdraw completely but later decided to provide on percent of the equity, leaving the other 13 percent to the other three countries. Singapore's decision was influenced by the fact that "...for and ASEAN project to qualify for concessional Japanese financing, the equity in each project must be held jointly by the five ASEAN countries." ${ }^{\text {42 }}$ This shows that the AIP was having a problem even at the very initial stage. There was a reluctance on the side of Singapore to participate in this industry because it did not have any interest in the products. Singapore's change of attitude, on the other hand, shows the importance of partnership with Japan at a time when ASEAN was embarking on economic cooperation. In 1978, Japan promised to provide US \$1 billion on concessional terms to help finance the five projects. ${ }^{43}$

Having done feasibility study and with Japan's assurance for concessions, ASEAN economic ministers signed the AIP agreement in 1980. However, of these five projects, only the two urea projects in Indonesia and Malaysia were operational. Between the two, about 85 percent of the Indonesian project's urea exports were absorbed by the other ASEAN countries. ${ }^{44}$ The AIPs failed because ASEAN was too ambitious in structuring the projects under the regional organization. It should be noted, however, that where there is a production capability, the projects can be easily carried out. The fact that the urea projects were feasible was because Indonesia and Malaysia already had the needed production base. Short of this needed production base, the other three projects did not materialize

The main reason for AIPs failure, then is that it should not have taken place in the first instance. There were good reasons for regional organization not to engage in this field since the responsibility for industrial targeting should be in the hands of national government. Langhammer suggests some reason for regional organizations not to engage in industrial projects. Firstly, industrial targeting "hand often proven to be ineffective at the national level because of external shocks, planners' inadequate knowledge of future market conditions and / or dispute between the central government and the federal states on regional policies inside an economy." 45 Therefore, intra - country level of economic management was prone to have problems since although the ASEAN member states were collaborators, they were also competitors. Secondly, "the assumption that industrial targeting within ASEAN was a national job from the very beginning is supported by the experience that it was costless to all member countries to run competing national policies against the AIPs." ${ }^{\text {"46 }}$

42 Business International Asia Research Report, op. cit., p. 70.

43. Ibid., p. 71.

44. Chatterjee, in Broinowski, ed., op. cit., p. 68.

45. Langhammer, op. cit. p. 140.

46. Ibid. 
Another reason for the incompatibility of these projects is to be found in the government and private sector roles. Seiji Naya and Michael Plummer do not see much of a future for the AIPs because: firstly, "government - to - government projects of this type are generally difficult to negotiate between all ASEAN countries as they tend to maximize bureaucratic interference," and secondly, "to the extend that they complete (or potentially complete) with private sector production, AIPs can be detrimental to private sector development; these projects are inherently inconsistent with the current privatisation trend in ASEAN." ${ }^{247}$ It is clear, therefore, that ASEAN cannot deal with the clashes of interest between the different national and private policies of the member states. In other words, the AIPs were inconsistent with the decentralized economic decision - making in private - sector based economies, and they collided with national industrial policies.

\section{The ASEAN Industrial Complementation}

The 1976 Bali Summit also discussed another industrial scheme which could complement the AIPs. It was named ASEAN Industrial Complementation (AIC), and after some discussions, the basic agreement on ASEAN AIC (BAAIC) was approved by the ASEAN foreign ministers in June 1981. Its basic idea was to extend intra - ASEAN industrial collaboration beyond just equity participation, a method used by the AIPs. It involved "liberalization of ASEAN trade in intermediate products at various phases in the production of a final product which has to be assembled in ASEAN." 48 The rationale of the project was that "[i]f industrial projects are integrated in a vertical manner so that production units specializing in the manufacture of parts are located in different countries, the commonality of interests of the participants might be improved. ${ }^{249}$ Put simply, different states were to produce certain items where they have the expertise and production capabilities, and to exchange the items through trade with other states participating in the scheme.

At its initial stage, the AIC scheme focused on the automotive industries. ASEAN member states were recommended to venture into the automotive collaboration by the ASEN Automotive Federation (AAF) in 1976. This recommendation urged the ASEAN states to undertake product exchange, which was obviously the main idea of the AIC scheme. However, the member states could not agree on the allocation of products among themselves, and by October 1983, only one project was

\footnotetext{
47. Naya, Seiji and Michael Plummer, "ASEAN Economic Cooperation in the New International Economic Environment," in ASEAN Economic Bulletin, Vol, 7, No. 3, March 1991, p. 272.

48. Naya and Plummer, op. cit. p. 264.

49. Chatterjee, in Broinowski, ed., op. cit., p. 69.
} 
undertaken under the AIC scheme. By the end of 1985, the total trade value of the AIC automotive project amounted to just over US \$ 1million, which was "no more than one percent of total intra ASEAN trading"50 The problem was also aggravated by Malaysia's and Indonesia's decisions to embark on their own automobile industry in the early $1980 \mathrm{~s}$.

The AIC then adopted a Brand to Brand Complementation (BBC) scheme, with the similar main objective of products exchange among the participating countries. However, unlike the first AIC scheme which needed to be decided by ASEAN economic ministers, the BBC scheme aimed at allowing "the private sector to determine the division of production." 51 Under the BBC scheme, ASEAN attracted many foreign automotive companies to participate in its efforts, the first being Mitsubishi, whose project was endorsed at the 1987 Manila Summit; later followed by Volvo, Mercedes Benz, Nissan, Toyota, and the DAF group from Belgium, whose projects were approved as of the $22^{\text {nd }}$ AEM (1990). ${ }^{52}$ This automotive collaboration was only participated by four member states, excluding Singapore and Brunei. As these projects are still in progress, not much is known of its progress and future prospects. Meanwhile, ASEAN agreed to extend the BBC program to include nonautomotive products in the $23^{\text {rd }}$ AEM (1991).

Before the introduction of the BBC, the main hindrance of the AIC was "the absence of established goals and guidelines which are shared by the interested private sector bodies and the respective ASEAN governments." ${ }^{53}$ Furthermore, the AIC was handicapped by a certain lack of trust amongst the member states involved in the projects as evidenced in the decisions of some members to start their own automotive industries. The $\mathrm{BBC}$, the, saved this aspect of collaboration with a more flexible approach toward the set up of the projects. In contrast with earlier ASEAN economic initiatives, the private sector was given the discretion to determine the division of production. Furthermore, the lengthy bureaucratic process which had to be faced by other projects was also cut down by allowing the Committee of Industry, Minerals and Energy (COIME) to work with the private sector in specifying the "brand, type, model, components and parts, as well as the product allocation among participating countries." $\$ 4$ The future of the BBC is bright, as Pangestu, at. al., rightly noted, "[t]he BBC scheme has better chance to succeed than the other ASEAN programs because there is quid pro quo." 55

50. Ibid.

51. Pangestu, et. al., op. cit. p. 338.

52. Ibid.

53. Chatterjee, in Broinowski, ed., op. cit. pp. 69-70

54 Pangestu, et. al., op. cit., p. 338.

55. Ibid. 


\section{The ASEAN Industrial Joint Ventures}

The ASEAN Industrial Joint Venture (AIJV) was introduced in 1993 with the aim at promoting intra - ASEAN investment. Unlike the AIPs and AICs where the participation came mainly from national governments, the AIJVs encourage the collaboration of private sectors and governments in industrial projects. The AIJVs also constitute yet a further step towards flexibility of procedures and decentralization from the 'all countries participation requirement' of AIPs and AICs. Its flexibility and decentralization can be seen through the requirements that "only two ASEAN countries needed to participate (and approval became less complicated), joint ventures with foreign capital were encouraged, and AIJVs could be of any scale." ${ }^{, 56}$ To make the program more attractive, its requirements were made to be different from the AIPs and AICs. The AIJVs should be participated by at least two ASEAN countries in a project where their combine equity should be more than 51 percent and no one of them should contribute less than 5 percent to the project. Their partner can come from any country or private sector outside ASEAN. However, an ASEAN - wide AIJV was more encouraged, with the goals of having a full ASEAN participation in the projects.

The minimum equity requirement was then relaxed at the 1987 Manila Summit such that applications submitted before December 1990 could have a minimum ASEAN equity of 40 percent. However, the tendency to extend the deadline happened when, at the $1990 \mathrm{AEM}$, the equity waiver was extended to December 1993; the 5 percent minimum equity of ASEAN partners was also waived; and the exclusivity privilege whereby protection is given in the form of restrictions to setting up a similar project under AIJV within a specified period of time was eliminated. ${ }^{57}$

Despite these several changes, AJV also suffered discouraging response. As of March 1992, only 18 products have been granted AIJV accreditation. ${ }^{58}$ Among the characteristics that can be observed in the AIJV scheme were: "a majority of AIJV have foreign equity participation; there are very few ASEAN - wide AIJV and there is only one AIJV having equity participation by all countries; there are problems with exporting, with some experiencing great difficulties in getting the margin of preference from the participating ASEAN countries; and plants and locations are concentrated in Thailand and Malaysia.",99

56. Naya and Plummer, op. cit., p. 265.

57. . Pangestu, et. al., op. cit, p. 337.

58. Ibid.

59. Ibid. 
In looking at its lack of progress, Langhammer suggested that the scheme "seems to be redundant (or at least not very relevant) for the private sector." ${ }^{60}$ This means that incentives offered by the scheme were not attractive enough or that they are simply redundant with the interests of the private sectors in ASEAN states who can well function outside the framework of AIJV. The factor of promotion was also important since the information about AIJV was not disseminated widely. Therefore, awareness of the scheme is low amongst ASEAN entrepreneurs and foreign investors. Another problem was the bureaucracy. The 'lengthy bureaucratic process of application' requires the interested party to obtain support from relevant government and has to wait for the governments concerned to agree and decide on the scheme, which can take a lot of time. ${ }^{61}$

Lessons from the First Phase of Intra - ASEAN Economic Cooperation

The first fifteen years (1976 - 1991) of economic cooperation in ASEAN was not very successful. Looking back at the region in this phase of economic cooperation, one would see the diversity and heterogeneity of the region as the major challenges faced by the member states. ASEAN member states are diverse in terms of economic development, political orientation, culture, history and religion. In its economic characteristics, it has the mixture of 'North' and 'South', in which; “[t]here is, on the one hand, the highly industrialized, affluent and small economy of Singapore, while on the other, the large, less affluent and rather dualistic economies of Indonesia, the Philippines and Thailand Then there is Malaysia which is medium - size, natural resource rich and relatively affluent; and finally Brunei which is affluent but structurally very different from the other five economies." ${ }^{\prime 62}$ This different level of economic development has indeed and adverse effect on ASEAN's collaborative programs.

ASEAN seems to have taken its intra - regional economic cooperation for granted. As in the case of the PTAs, AIPs, AICs and AIJVs, the member states designated the programs to the supranational body. Thus, in the meetings of the AEM, consensus can hardly be reached on substantive issues. This is further aggravated by the fact that ASEAN member states were focusing more on extra ASEAN trade. Langhammer had rightly noted this when he said, "[g]iven this strong orientation of all ASEAN member countries toward extra - ASEAN trading patterns, there is much reason to argue that national trade policies are widely independent from each other and thus can be defined as a national and not supranational job." 63

60. Langhammer, op. cit, p. 141.

61. Pangestu, et. al,, op. cit. p. 337.

62 Chatteriee, op. cit. p. 143. 
Yet another critical issue in economic cooperation concerns with the question of authority for industrial planning. Since ASEAN could not develop an integrated economy due to its economic structure and complementarity, like trade policies, a supranational body cannot be given the responsibility of industrial targeting. This is specially true in the case of AIPs and AICs which pointed to the fact that they should be initiated by national by national governments, not ASEAN. The failure of the AIPs and AICs "bears witness to the responsibility of national authorities for industrial policy guidance and of the private sector for implementation. There is no ASEAN role for industrial targeting. ${ }^{\prime 64}$ Since AIPs are practically not functioning, while the AICs survive with the collaboration of the private sector; the member states can opt for giving more roles to be played by the private sectors in industrial cooperation. In this regard, the AIJVs can be a guide, although they need to operate in an environment of simpler procedures and less bureaucratic red - tape.

As of now, one apparent weakness of ASEAN economic cooperation can be found in its organizational structure. ASEAN economic cooperation falls under the responsibility of ASEAN Economic Ministers, whose works are based upon the report of five committees:

i. Committee on Trade and Tourism (COTT)

ii. Committee on Industry, Minerals and Energy (COIME)

iii. Committee on Finance and Banking (COFAB)

iv. Committee on Food, Agriculture and Forestry (COFAF)

v. Committee on Transportation and Communications (COTAC) ${ }^{63}$

Under this set up, two different committees are responsible for trade and industry, where each of them are merged with other economic subjects. This is indeed different from the realities of ASEAN economic cooperation where trade and industry are being coordinated hand - in - hand. This organization structure also implies that the coordination of various economic projects may be done ad hoc. Taking into account the current changes in ASEAN economic cooperation, a change of this organizational structure should be logical. The much needed change is to have a specific committee on trade and industry. This change can indeed help improve ASEAN's mechanism since the second phase in intra - ASEAN economic cooperation deals primarily with trade liberalization amongst the member states.

64. Ibid., p. 147

65. Chatterjee, in Broinowski, ed., op. cit, p. 60. 


\section{A TRANSITION TO ECONOMIC INTEGRATION}

The economic cooperation which began since 1976 has provided the picture of a failed collaboration. However, ASEAN leaders were not bothered by this failure. They agreed on some other projects which need further serious commitment from amongst themselves. The $23^{\text {rd }}$ ASEAN Economic Ministers Meeting in 1991 has agreed to carry out some new projects, namely; the Common Effective Preferential Treatment, the Growth Triangle concept, the ASEAN Free Trade Area; and the signing up of the Framework Agreement on Enhancing ASEAN Economic Cooperation. This time around, ASEAN did not discuss the possibilities to create new industrial projects which were problematic in the first phase of its economic cooperation.

At the Fourth ASEAN Summit (1992), all the six heads of government spoke on the need for greater economic integration, as proposed by the $23^{\text {rd }} \mathrm{AEM}$, in the face of growing regionalism and the prospect of more intense competition for foreign investment in the region. Singapore's Prime Minister Goh Chok Tong referred to the single European market and the North American Free Trade Agreement as "defining the new operating environment for ASEAN." these other regions in attractiveness, investment would start flowing away from the region. This concern was also reflected in point 2 of the Singapore Declaration 1992:

"2. Having reviewed the profound international political and economic changes that have occurred since the end of the Cold War and considered their implications for ASEAN, we declare that:

- ASEAN shall constantly seek to safeguard its collective interests in response to the formation of large and powerful economic groupings among the developed countries, in particular through the promotion of an open international economic regime and by stimulating economic cooperation in the region;...,67

The new economic programs as agreed upon in 1991 and 1992 showed that ASEAN was willing to continue improving the economic ties they have developed since 1976. With the motivation of strengthening its institutional - building and to react upon perceived loss of trade due to the growing regionalism in other parts of the world, ASEAN established the Common Effective Preferential Treatment, the Growth Triangle Concept, the ASEAN Free Trade Area, and the Framework Agreement on Enhancing ASEAN Economic Cooperation. A striking feature of these schemes in that ASEAN did

66. Vatikiotis, Michael, "ASEAN: Action at Last," in Far Eastern Economic Review, February 6, 1992, p. 10.

67. Singapore Declaration of 1992, in ASEAN Economic Bulletin, Vol. 8, No. 3, March 1992, p. 376. 
not propose any new industrial project, the area it failed to progress substantially before. The following sub - sections will provide a brief description on each of these projects, examine its progress, and discuss some of the issues which arise in the process of implementing these programs.

\section{The Common Effective Preferential Treatment}

The Common Effective Preferential Treatment was suggested by Indonesia in the $23^{\text {rd }}$ AEM in 1991. It can be seen as Indonesia's concern over the eagemess of ASEAN member states toward liberalization of ASEAN market without due consideration to economic realities of the member states. The rationale for the CEPT is to allow member states to be fully prepared for trade liberalization through a tariff - cutting mechanism. In this observation of the Fourth ASEAN Summit, Michael Vatikiotis wrote, "[w]orking on the principle that ASEAN moves as fast as its slowest member, CEPT became the mechanism for establishing AFTA."68

The CEPT provides a framework in which by the set deadline, the tariff rates would be nil, or at an maximum, 5 percent. The Singapore Declaration of 1992 outlined fifteen groups of products to be included in the CEPT scheme for tariff reductions: "vegetable oil, cement, chemicals, pharmaceuticals, fertilizer, plastics, rubber products, lather products, pulp, textiles, ceramic and glass products, gem and jewelry, copper cathodes, electronics, and wooden and rattan furniture."69

It should be duly noted that before the adoption of the CEPT scheme, ASEAN was referring to the PTA as the mechanism to facilitate intra - ASEAN trade. However, unlike the PTA that remains an ambiguous concept for its various requirements and the absence of a deadline, the CEPT establishes a clearer vision through its pre - negotiated tariff reduction and an agreed deadline. Another striking difference is that the PTA is granted only by the nominating country without reciprocity, whereas "... under CEPT there is reciprocity in that once the good is accepted by all countries or accepted subset of countries (other countries to follow in three years), then all countries or subset thereof must give the preferential tariff." ${ }^{70}$ In other words, the CEPT aims at providing a uniform preferential treatment for the realization of intra - ASEAN trade liberalization.

Since the CEPT is viewed as reflecting the ASEAN economic realities, efforts to achieve its objective have been gradual in nature. There are four tariff groups at the beginning of this scheme: 0 $5 \%, 5-10 \%$, and $15-20 \%$. To be eligible for the CEPT, a product has to satisfy three conditions:

68. Vatikiotis, op. cit.

69. The Singapore Declaration of 1992, op. cit.

70. Pangestu, et. al., op. cit. p. 346. 
"the product has to be on the Inclusion List of both the exporting and importing country; it must have an approved tariff reduction schedule, except for products with tariffs already at or below 5 percent; and it has to be an ASEAN product, with a local content requirement of 40 percent, on a single country or on a cumulative ASEAN basis."71

The CEPT scheme, furthermore, is designed to be flexible so that member states can make adjustments necessary for its attainment. In view of this, the scheme allows member countries to arrange for exclusion lists, in which several items would be exempted from trading preferential. There are three categories of exclusions: "temporary exclusions, which will be reviewed after eight years; general exceptions, on the grounds of national security, public morals, and so on; and unprocessed agricultural products." ${ }^{72}$ this exclusion list, however, would affect the effectiveness of the CEPT, and hence, AFTA. Pangestu, et.al., observed that such “...exclusion lists are reminiscent of the early days of PTA and runs counter to the initial proposal of not having an exclusion list." ${ }^{73}$ The reason behind having the exclusion lists was mainly due to the varying degrees of industrialization and the unpreparedness of the member countries to surrender their national priority to the common trading arrangements.

Another obvious issue in the CEPT is on the status of PTA in the presence of the CEPT. The ASEAN economic ministers agreed that the two will be merged, but it is not clear how this should occur. The ways being considered by ASEAN are to let both the schemes run parallel, or to place the PTA under the CEPT. To avoid confusion, the preferred way would be "to subsume the PTA under the CEPT since the latter is more encompassing." ${ }^{74}$ However, no decision is made yet on the nature of the merging of the two schemes. Despite its weakness, it should be acknowledged that this time around, the member states have shown a positive sign by agreeing to commit themselves with a set deadline, which is clearly missing in ASEAN collaborative efforts before.

Furthermore, "[t]he announcement of the schedule of tariff reductions which will occur in the future will give businesses time to adjust and to restructure."75

\footnotetext{
71. Lee Tsao Yuan, "The ASEAN Free Trade Area; The Search for a Common Prosperity," in Garnaut, Ross and Peter Drysdale, ed., Asia Pacific Regionalism: Readings in International Economic Relations, (New South Wales: HarperEducational, 1994), p. 321.

72 Ibid.

73. Pangestu, et. al., op. cit., p. 346.

74. Ibid. p. 347.

75. Lee Tsao Yuan, op. citto p. 322.
} 


\section{The Growth Triangles}

The concept of Growth Triangles in Southeast Asia has existed even before it became an ASEAN project in 1991 , as agreed in the $23^{\text {rd }}$ AEM. The Singapore - Johor (Malaysia) - Riau (Indonesia) [SIJORI] Growth Triangle was already formalized in 1989. other proposed growth triangles within ASEAN include: Penang (Malaysia) - Medan (Indonesia) - Phuket (Thailand); Eastern Acheh (Indonesia) - Medan (Indonesia) - Penang (Malaysia); and Kalimantan (Indonesia) - Sabah (Malaysia) - Mindanao (the Philippines).

The 'growth triangles' concept is an attempt at integration in the sub - regional level. It is a test of willingness on the part of the different states to exploit the complementarity of their economies. In terms of SIJORI, Riau and Johor are excepted to provide land, labour and resources such as water; whereas Singapore will provide the supporting infrastructure such as finance, transportation and telecommunications, skilled labour, management and access to the world market. Batam, an island in the Riau groups of island, is the main beneficiary of the project. It was declared a duty free zone in 1978, and "only when policy changes occurred in 1989 on the Indonesia side plus tacit support by the Singapore government, did foreign investors (outside of oil - related activities) began to seriously consider locating in Batam." 76 The policy change by the Indonesia government of allowing 100 percent foreign investment in the island has attracted foreign investors, especially from Singapore and Johor, to set up industrial estates in Batam.

The growth triangles can help the less developed areas to exploit their potentials through the help of their richer neighbours. Chia Siow Yue and Lee Tsao Yuan characterized SIJORI as a "metropolitan spillover into the hinterland"; essentially a growth pole spillover phenomenon in a transnational context". ${ }^{77}$ Consequently, the main actor of this type of collaboration is understandably the richest, i.e., Singapore. SIJORI can be viewed as stemming from a natural evolution of cooperation between the three areas before it was formalized. Johor, the southernmost state of peninsular Malaysia, has been supplying water to Singapore since 1962. Singapore companies and subsidiaries, on the other hand, have expended or relocated to Johor for reasons of rising costs, the unavailability of labour, and the shortages and rising costs, Batam became increasingly considered as an alternative.

The economic rationale for the promotion of SIJORI is that "it makes possible the development of the subregion, capitalizing on the resource complementarity and geographic proximity

76. Pangestu, op. cit. p. 339.

77. Chia Siow Yue and Lee Tsai Yuan, "Subregional Economic Zones in Southeast Asia," in Garnaut and Drydale, op. cit. p. 367. 
of the three component areas." ${ }^{, 78}$ SIJORI has an area of 20000 square kilometres and a population of 5 million, with a range of GDPs per capita between nearly US \$4000 in Johor, less than US \$1000 in Batam, to over US \$ 12500 in Singapore (see Table 5). In numerical terms, it seems to be ideal for SIJORI to function well since it provides a certain degree of complementarity to be accorded.

TABLE 5: Basic Indicators for SIJORI Growth Triangle

\begin{tabular}{|c|cccc|}
\hline Indicators & Johor & Singapore & Riau & Total \\
\hline Area $\left(\mathrm{km}^{2}\right)$ & 18,914 & 639 & 3,300 & 22,583 \\
\hline Population $($ million) & 2.2 & 2.8 & 0.1 & 5.1 \\
GDP (US $\$$ million) & 4,300 & 34,600 & 45 & 38,945 \\
\hline GDP/Capita (US $\$$ ) & 3,954 & 12,940 & 500 & \\
\hline Growth Rate of GDP $(\%)$ & 9.0 & 6.7 & n.a & \\
\hline
\end{tabular}

Source: Chia Sow Yue and Lee Tsao Yuan, Subregional Economic Zones in Southeast Asia, in Asia Pacific Regionalism; Readings in International Economic Relations, (New South Wales: Harper Educational, 1994), p. 368.

In practice, however, SIJORI faces various problems that are characteristic of other ASEAN economic endeavours. At present, the nature of its collaboration is not fully formalized. Under the present set up, "there are two bilateral agreements: between Singapore and Indonesia, and between Singapore and Malaysia. However, there is no formal agreement between Malaysia and Indonesia."79 Furthermore, in terms of investment and trade relations, Johor and Riau tend to be competitive rather than complementary. Another problem relates to the fact that unlike Singapore and Batam, Johor is not a free trade zone. In addition, "since Johor is a much mire substantial part of Malaysia than Riau relative to the rest of Indonesia, the dimensions of the problem are greater for Malaysia." 80

\section{ASEAN Free Trade Area}

At the $23^{\text {rd }}$ ASEAN Economic Ministers Meeting, the ASEAN Free Trade Area (AFTA) was proposed by Thailand, seconded by Singapore. The proposal was later discussed and agreed by the heads of government in the $4^{\text {th }}$ ASEAN Summit in 1992. In the $23^{\text {rd }}$ AEM, "Singapore and Malaysia had wholly supported the FTA proposal. Indonesia and the Philippines had some reservations on how fast they should go." ${ }^{81}$ In this regards, there exists a certain degree of hesitancy amongst some member states on the question of integration in economic sphere. Nonetheless, AFTA is by the most ambitious project undertaken by ASEAN. with the CEPT being the vehicle of AFTA, ASEAN envisions to have a fully liberalized market by the year 2008 .

7h. Ibid. p. 368 .

79. Pangestu, et al, op. cit. p. 340 .

BO. Ibid.

11. Ibid. p. 345. 
A positive sign in ASEAN's economic collaboration can be found in the willingness of the member states to set a deadline for the achievement of AFTA. The only disagreement that they have was on when the deadline should be set. There were at least two proposed deadlines; Thailand suggested a ten years deadline (2002), while ASEAN - ISIS ${ }^{82}$ proposed for a fifteen years one. ${ }^{83}$ Consequently, ASEAN heads of government opted the fifteen years deadline, but instead of the proposed 2007, it set 2008 as the deadline so that needed preparations can be done before January 1 , 1993. The decision to achieve AFTA in 15 years showed the influence of 'track - two', the ASEAN ISIS, to the high - level decision - making in ASEAN.

With the CEPT as the modus in achieving AFTA, another question arise: what is the scope of AFTA? The ideal form of a free trade area is that a product from a country can move freely across the border of the contracting states. However, this is not feasible in ASEAN because of the varying degrees of economic growth of the member states. Thus, two aspects were considered: "first is whether an across the board or sectoral approach is adopted, and second, which trade barriers are to be included" ${ }^{\prime \prime 4}$ Although across the board approach is easier to administer and more efficient, for reasons of competitiveness in ASEAN market, the member states has adopted the sectoral approach. Since free trade is directed toward certain sectors, some other sectors are prone to be excluded. Here again, the CEPT is needed as the forum for determining which sectors to be included, and to what extent should be trade barriers.

Other issues that are still plaguing AFTA include the status of non - tariff barriers and the rule of origin. As of now, "[m]any ASEAN states deploy a wide range of non - tariff barriers including domestic requirements, discriminatory government procurement practices, licensing for the distribution of certain products, local content and counterpurchase requirements, and the often arbitrary application of customs classification and valuations." ${ }^{85}$ The main problem in this issue is that there are no comprehensive survey on the impact of these barriers to ASEAN economic cooperation. The non tariff barriers remain to be removed, thus making the accomplishment of AFTA difficult.

Another unclear agreement in AFTA concerns with the rules of origin. For a product to be considered as an ASEAN product, it has to have 40 percent of its content originated from ASEAN, but "how the 40 percent is to be calculated has not been agreed to."

82. ASEAN - ISIS is a network of various Institutes of Strategic and International Studies which exist in ASEAN. it constantly recommends to various ASEAN committens on several policies, ranging from political, security and economic.

в. Pange日tu, et. al., op. cit., p. 345.

84. Ibid. p. 346.

85. Ravehill, op. cit., p. 860

86. Akrasanee, Narongchai and David Stifel, "The Political economy of The ASEAN Free Trade Area," in Garnaut and Drysdale, op. cit. p. 333. 
products come from Singapore or Brunei. "As Singapore and Brunei are free ports, other ASEAN states are concerned that goods originating outside the region will be diverted through these ports and relabelled as ASEAN products. ${ }^{587}$ This lack of specificity in the question of rules of origin, therefore, would be a sensitive matter since they are open to corruption and falsification of documents. ASEAN's hesitancy to commit into specific provisions of the free trade agreement implies that its member states are not yet fully prepared to enter into regional economic integration. Ravenhill's observation of this scenario further explains the mood in achieving AFTA:

"Contrast, for instance, the dozen or so pages of the Singapore Declaration with the more than 1000 pages of the North American Free Trade Agreement. The consequence of this lack of detail in the Singapore Declaration is that many keys issues are unresolved and will have to be negotiated at the same time as the member states are scheduled to be implementing tariff reductions - causing AFTA to be dubbed 'Agree First, Talk After', ,"88

AFTA's lack of specificity also led to a confusion on its legal status. While other member states view it as not being a treaty, the Thailand's legislature criticized its then prime minister who signed the AFTA agreement for ignoring the legislative process in the country. The Thai House committee also charged "that Mr. Anand (then Prime Minister) signed the agreement unilaterally, without consulting the business sector." ${ }^{289}$ The committee believed that AFTA would hurt the Thai's production of vegetable oil, plastic pallets, glass and mirror products, electrical goods, rubber products and leather goods. Prime Minister Anand, however, defended that "he was authorized by a Cabinet decision that did not need ratification." ${ }^{90}$ He was also defended by the Commerce ministry, in which one of its highly placed official argued "that the AFTA agreements did not need ratification because they were extensions of existing ASEAN economic cooperation agreements." ${ }^{\text {91 }}$ Although this issue has been resolved when the legislature finally agreed with Prime Minister Anand's signing of the agreement, the fact that it was brought up indicates that there was a misunderstanding amongst the politicians in Thailand about the nature of AFTA. It was ironic that this issue was raised in the very state that originated the ideal of AFTA.

Despite all these problems, AFTA is given high expectation to help develop ASEAN to be a prosperous market place. It will also help elevating ASEAN to be a more attractive region for investors

87. Ravenhill, op. cit. p. 860.

88. Ibid. p. 859.

88. Bangkok Post, November 23, 1991.

90. .

91. Ibid. 
from outside the region because "many foreign investors favoured liberalization of intra - regional trade and welcome the prospect dor a region - wide market." 92 AFTA may also benefit ASEAN producers as well. ASEAN's cooperation in reducing tariff and non - tariff barriers through a free trade area can strengthen the relationship of the member states' business sectors. Finally, the positive aspect of this arrangement, as rightly put by Akrasanee and Stifel, is that, "ASEAN solidarity as exemplified in AFTA - especially now that a general commitment has been made - will allow the group to have a greater say in the international community and to address its concern over the trading system." ${ }^{.93}$

\section{The Framework Agreement on Enhancing ASEAN Economic Cooperation}

As stated before, ASEAN was unprepared to commit itself into a more inward - looking economic integration. This fact is further strengthened by the refusal of ASEAN member states to enter into a treaty on economic cooperation. In the $23^{\text {rd }}$, the Philippines suggested that an ASEAN Economic Treaty would be signed in the Fourth Summit (1992). However, this idea did not receive much support since the member states were reluctant to commit themselves into an internationally binding agreement. The meeting, then, settled with a bless binding document, which was named "The Framework Agreement on Enhancing ASEAN Economic Cooperation," which was later signed by the heads of government at the Fourth summit in 1992

The agreement, although not binding, was written with the characteristic of a treaty. There are fifteen 'articles' in this framework agreement. Among the major points of the agreement are:

i) Strengthening various areas of cooperation (e.g., trade, industry, finance, banking, food agriculture, forestry, transportation, and communication)

ii) Strengthening extra - ASEAN economic cooperation

iii) Encouraging private sector participation

iv) Giving ASEAN Secretariat the function of a monitoring body, and

v) Enhancing sub - regional cooperation. ${ }^{94}$

An interesting, if not ambitious, provision lies in Article 9, concerning 'Settlement of Disputes." The article states, "[a]ny differences between the Member States concerning the interpretation or application of this Agreement or any arrangements arising there from shall, as far as possible, be settled amicably between the parties. Whenever necessary, an appropriate body shall be

92. Ravenhill, op. cit. p. 856.

93. Akrasanee and Stifel, op. cit, p. 329.

94 For the full text of the "Framework Agreement on Enhencing ASEAN Economic Cooperation", see Appendix 3. 
designated for the settlement of disputes." ${ }^{.95}$ This provision, however is still vague because it did not specify what kind of mechanism to be established in case of disputes. Rather, it ended up with an ad hoc approach to solve disputes when they cannot be settled by the parties involved.

\section{The Future of the Second Phase in Intra - ASEAN Economic Cooperation}

The push toward economic integration in ASEAN is a hasty decision. Events following the $23^{\text {rd }}$ AEM have shown that the member states are not well - prepared to venture into such arrangements. The move toward achieving AFTA was also hindered by suspicions and the lack of trust amongst the member states. As Malaysia, Thailand, Indonesia and the Philippines are developing countries, they want to protect their market and some industries to remain competitive. Therefore, ASEAN's economic cooperation cannot be understood as an effort to take advantage of its economic complementarity, as ASEAN wants other to believe. Rather, "the reasons lie more in the recent developments of ASEAN economies, which have changed to cope with the new international trade and investment trends. ${ }^{.96}$ In this sense, the new phase in intra - ASEAN economic cooperation is galvanized by economic motives which can be manifested in the large regional association.

The second phase of intra - ASEAN economic cooperation has also strengthened its institution - building. The regular process of interaction amongst the member states has improved their understanding in dealing with world economic issues. Today, ASEAN is one of the major players in APEC. ASEAN member states agreed to participate in APEC subject to "their so called 'three noes': that APEC has no legally binding authority, that it has no negotiating right, and that it pursue no regional arrangements beyond those reached in the GATT, ${ }^{, 97}$ At the Second APEC Summit meeting in Bogor, Indonesia (1994), ASEAN was successful in its attempt to get all members agreed for a dual deadline resolution for trade liberalization in APEC; 2010 for the developed, and 2020 for the developing countries. In Osaka, Japan (1995), during the Third APEC Summit meeting, it had again successfully lobbied dor the adoption of an Action Agenda for APEC which is "voluntary and flexible" which means that "there is no obligation on any member to liberalize their markets, be it by 2010 or 2020." What ASEAN did here was to introduce the "ASEAN way" of decision making to the APEC process. The message signalled by ASEAN was that APEC can have a timeframe, but the

95. Ibid. p. 384.

96. Akrasanee and Stifel, op. cit. p. 329.

97. Rudner, Martin, "APEC: The Challenges of Asian Pacific Economic Cooperation", in Modern Asian Studies, Vol.

29, Part 2, May 1995, P. 413.

98. Kaur, Hardev, "A Lesson in Realism for APEC", in Business Times (Malaysia), November 23, 1995, p. 4. 
implementation should be pragmatic, taking into account the various levels of development amongst its members. This also shows that ASEAN's institution - building efforts are significant in shaping its role in a wider regional arrangement.

ASEAN's march toward economic integration through the vision of AFTA can be rationalized as its reaction toward the trends of economic regionalism in North America and Europe. The reaction was to form its own grouping rather than waiting and calculating the costs and benefits of such trends. ASEAN's main weakness is that the member states of ASEAN seem to be coping other regions' integrational measures (e.g., NAFTA and EC) without having a strong foundation for such efforts. Prior to the establishment of AFTA, statistics, as shown in Table 2 (page 14), indicated that intra ASEAN trade was minimal. In this sense, ASEAN was pursuing a somewhat ambiguous economic integration, leading it to be labelled as having 'names first, substance later'. ${ }^{99}$ As a result, ASEAN economic cooperation depends largely upon the ensuing ad hoc negotiations and agreements after certain projects are adopted.

Attention in ASEAN is now being directed toward AFTA. It can be a measure to further evaluate ASEAN economic integration. Only if AFTA furnctions well can ASEAN be said as being successful in its integrational approach. In this regard, the CEPT's mode should be improved so that its mechanism to eliminate tariff (and non - tariff) barriers can be effective by the set deadline of achieving AFTA. Still another aspect that ASEAN should consider is the position of Vietnam in AFTA. As AFTA was formalized prior to Vietnam's membership in ASEAN, an adjustment had been made to facilitate Vietnam's position in AFTA. Under the arrangement, Hanoi agreed to participate in AFTA "... after being granted the concession of an additional three years to implement CEPT."100

While working on AFTA and CEPT, it is indeed wise for ASEAN to carry on and improve its subregional cooperation, i.e., the growth triangles. The gtowth triangles have proven to be giving more immediate benefits and have less controversial issues. They can also forge greater understanding among the states involved which may lead to consensus and compromise in other joint economic endeavours.

99. See for example, Langhammer, op. cit. pp. 137 - 138.

100. Ravenhill, op. cit, p. 866. 


\section{CONCLUSION}

Although intra - ASEAN economic cooperation measures were plagued by many problems, the member states are still giving it considerable attention. It should be noted that issues in this area of cooperation involve only the degree of success or failure of such cooperation and the feasibility of its projects, and not the survival of the association. ASEAN remains to be a major player in the Southeast Asian region because of the understanding amongst its elites. To borrow Marjorie Suriyamongkol's term, ASEAN leaders play the 'politics of avoidance and the rhetoric of unity' ${ }^{101}$ in their continued optimism for the various collaborative efforts. In the meantime, however, no serious controversies had arisen from this cooperation. In so far as the cooperation is unsuccessful, its failure does not lead ASEAN into conflict amongst the member states. The various issues faced by ASEAN indicate that the member states are willing to cooperate in economic areas, but at the same time, opting for some degrees of protectionism for their own national resilience and economic growth

This paper has evaluated the progress of various efforts to achieve economic integration in ASEAN, since some of its programs, particularly after the $23^{\text {rd }}$ AEM Meeting in 1991, appeared to have the characters of economic integration. As this research has shown, ASEAN is not integrating its economy despite the existence of AFTA and CEPT. Although there are some efforts to integrate ASEAN's economy, at present, it is unlikely. This is due to factors such as the heterogeneous nature of the region, economies which still need a certain degree of protection for several products, and weak organizational structure. A new perspective on intra - ASEAN economic cooperation, is therefore, a perspective of paradox; the insistence of ASEAN to continue with economic cooperation in spite of relative failure in the pre -1991 economic collaboration.

The new economic cooperation measures as agreed in 1991 have provided a new raison d'être for ASEAN's existence. The outcome of these efforts will largely depend upon the effectiveness of the CEPT as a tariff - cutting mechanism. Ta achieve AFTA, the tariff rates should be in the range of $0-5$ percent by 2008. The main problem faced by ASEAN at the moment is the tendency to delay the implementation of programs already agreed by the organization. A brighter spot in the second phase of intra - ASEAN economic cooperation, nonetheless, lies in the growth triangle concept.

\footnotetext{
101. See Suriyamongkol, Marjorie L., Politics of ASEAN Economic Cooperation, (Singapore: Oxford University Press, 1988), pp. $52-56$.
} 
This sub - regional arrangement can be more effective than other programs since its focus is smaller and it is designed to exploit economic complementarity between the participating economic areas. The absence of a legally - binding document to facilitate all these mechanisms is, on the one hand, a hindrance for the achievement of a liberalized ASEAN market. On the other hand, it also requires the strengthening of institution - building amongst ASEAN member states through deliberation of ways to improve the achievement of the aims and goals of the projects.

The main stumbling block in intra - ASEAN economic cooperation, as pointed out by many observers (Naya, Langhammer, Ravenhill, Pangestu, to name but a few), is the member states' political will. ASEAN's progress in adopting various programs are often handicapped by the inability of the leaders to implement them for suspicions of other states' commitment. The case in point are the various industrial cooperation adopted since 1976 (AIPs, AICs, AIJVs). Political commitment remains to be a serious issue, and ASEAN economic initiatives will depend much upon the willingness of the member states to sacrifice for the successful implementation of their economic programs. Alongside political will, ASEAN should remain committed to its concept of open regionalism. For its economies to enjoy further growth; while strengthening its economic cooperation, it has to remain open to international trade and extra - ASEAN cooperation.

ASEAN has gone a long way in its two phases of intra - regional economic cooperation. Intra - ASEAN economic cooperation, as this paper shows, is motivated by institution - building and as a reaction toward economic regionalism elsewhere. However, both rationales cannot ensure the success of ASEAN's visions to integrate the regional economy. The challenge for ASEAN is to translate its visions into workable economic mechanisms through unswerving political commitment and honouring the many agreements made to achieve a truly liberalized economy in Southeast Asian region. ASEAN should also learn from its past mistakes so that it will not repeat them in the process of accomplishing an ASEAN Free Trade Area by the year 2008. 


\title{
APPENDIX 1
}

\section{DECLARATION OF ASEAN CONCOND}

\author{
A Common Bond Existing among the
}

Member States of the Association

of Southeast Asian Nations

The President of the Republic of Indonesia, the Prime Minister of Malaysia, the President of the Republic of the Philippines, the Prime minister of the Republic of Singapore and the Prime Minister of the Kingdom of Thailand,

REAFFIRM their commitment to the Declarations of Bandung, Nagkok, and Kuala Lumpur, and the Charter of the United Nations; member states;

ENDEAVOUR to promote peace, progress, prosperity and the welfare of the peoples of

UNDERTAKE to consolidate the achievements of ASEAN and expand ASEAN cooperation in the economic, social, cultural and political fields;

\section{DO HEREBY DECLARE}

ASEAN cooperation shall take into account, among others, the following objectives and principles in the pursuit of political stability:

1. The stability of each member state and of the ASEAN region is an essential contribution to international peace and security. Each member state resolves to eliminate threats posed by subversion to its stability, thus strengthening national and ASEAN resilience.

2. Member states, individually and collectively, shall take into active steps for the early establishment of the Zone of Peace, Freedom and Neutrality.

3. The elimination of poverty, hunger, disease and illiteracy is a primary concern of member states. They shall therefore intensify cooperation in economic and social development, with particular emphasis on the promotion of social justice and on the improvement of the living standards of their peoples.

4. Natural disasters and other major calamities can retard the pace of development of member states. They shall extend, within their capabilities, assistance for relief of member states in distress.

5. Member states shall take cooperation action in their national and regional development programmes, utilizing as far as possible the resources available in the ASEAN region to broaden the complementarity of their respective economies.

6. Member states, in the spirit of ASEAN solidarity, shall rely exclusively on peaceful processes in the settlement of intra - regional differences.

7. Member states shall strive, individually and collectively, to create conditions conducive to the promotion of peaceful cooperation among the nations of Southeast Asia on the basis of mutual respect and mutual benefit.

8. Member states shall vigorously develop an awareness of regional identity and exert all efforts to create a strong ASEAN community, respected by all and respecting all nations on the basis of mutual advantageous relationships, and in accordance with the principles of self determination, sovereign equality and no - interference in the international affairs of nations. 


\section{AND DO HEREBY ADOPT}

The following programme of action as a framework for ASEAN cooperation:

\section{A. Political}

1. Meeting of the Heads of Government of the member states as and when necessary.

2. Signing of the Treaty of Amity and Cooperation in Southeast Asia.

3. Settlement if intra - regional dispute by peaceful means as soon as possible.

4. Immediate consideration of initial steps towards recognition and respect for the Zone of Peace, Freedom and Neutrality wherever possible.

5. Improvement of ASEAN machinery to strengthen political cooperation.

6. Study on how to develop judicial cooperation including the possibility of an ASEAN Extradition Treaty.

7. Strengthening of political solidarity by promoting the harmonisation of views, coordinating position and, where possible and desirable, taking common actions.

\section{B. Economic}

\section{Cooperation on Basic Commodities, particularly Food and Energy}

* Member states shall assist each other by according priority to the supply of the individual country's needs in critical circumstances, and priority to the acquisition of exports from member states, in respect of basic commodities, particularly food and energy.

* Member states shall also intensify cooperation in the production of basic commodities particularly food and energy in the individual member states of the region.

\section{Industrial Cooperation}

* Member states shall cooperate to establish large - scale ASEAN industrial plants, particularly to meet regional requirements of essential commodities.

* Priority shall be given to projects which utilize the available materials in the member states, contribute to the increase of food production, increase foreign exchange earnings or save foreign exchange and create employment.

\section{Cooperation in Trade}

* Member states shall cooperate in the fields of trade in order to promote development and growth of new production and trade and to improve the trade structures of individual states and among countries of ASEAN conducive to further development and to safeguard and increase their foreign exchange earnings and reserves.

* Member states shall progress towards the establishment of preferential trading arrangements as a long term objective on a basis deemed to be at any particular time appropriate through rounds of negotiations subject to the unanimous agreement of member states.

* The expansion of trade among member states shall be facilitated through cooperation on basic commodities, particularly in food and energy and through cooperation in ASEAN industrial projects.

* Member states shall accelerate joint efforts to improve access to markets outside ASEAN for their raw materials and finished products by seeking the elimination of all trade barriers in those markets, developing new usage for these products and in adopting common approaches and actions in dealing with the regional grouping and individual economic powers. 
* Such efforts shall also lead to cooperation in the field of technology and production methods in order to increase the production and to improve the quality of export products, as well as to develop new export products with a view to diversity exports.

\section{Joint Approach to International Commodity Problems and other World Economic Problems}

* The principle of ASEAN cooperation on trade shall also be reflected on a priority basis in joint approaches to international commodity problems and other world economic problems such as the reform of international trading system, the reform of international monetary system and transfer of real resources, in the United Nations and other relevant for a, with a view to contributing to the establishment of the New international Economic Order.

* Member states shall give priority to the stabilisation and increase of export earning of those commodities produced and exported by them through commodity agreements including buffer stock schemes and other means.

\section{Machinery for Economic Cooperation}

Ministerial meetings on economic matters shall be held regularly or as deemed necessary in order to:

* Formulate recommendations for the consideration of Governments of member states for the strengthening of ASEAN economic cooperation.

* Review the coordination and implementation of agreed ASEAN programmes and projects on economic cooperation.

* Exchange views and consult on national development plants and policies as a step towards harmonising regional development; and

* Perform such other relevant functions as agreed upon by the member Governments.

\section{Social}

1. Cooperation in the field of social development with emphasis on the well - being of the low - income group and of the rural population, though the expansion of opportunities for productive employment with the fair remuneration.

2. Support for the active involvement of all sectors and levels of the ASEAN communities, particularly the women and youth, in development efforts.

3. Intensification and expansion of existing cooperation in meeting the problems of population growth in the ASEAN region, and where possible, formulation of new strategies in collaboration with appropriate international agencies.

4. Intensification of cooperation among member states as well as with the relevant international bodies in the prevention and eradication of the abuse of narcotics and the illegal trafficking of drugs.

\section{Cultural and Information}

1. Introduction of the study of ASEAN, its member states and their national languages as part of the curricula of schools and other institutions of learning in the member states.

2. Support of ASEAN scholars, writers. Artists and mass media representatives to enable them to play an active role in fostering a sense of regional identity and fellowship.

3. Promotion of Southeast Asian studies through closer collaboration among national institutes. 


\section{E. Security}

Continuation of cooperation on a non - ASEAN basis between the member states in security matters in accordance with the mutual needs and interests.

\section{F. Improvements of ASEAN Machinery}

1. Signing of the Agreement on the Establishment of the ASEAN Secretariat.

2. Regular review of the ASEAN organizational structure with a view to improving its effectiveness.

3. Study of the desirability of a new constitutional framework for ASEAN.

DONE at Denpasar, Bali, this twenty - fourth day of February in the year one thousand nine hundred and seventy - six.

SOURCE: Law and Practice under the GATT: The Association of Southeast Asian Nations, compiled and edited by Paul Davidson, (New York: Oceana Publications, 1995). 


\section{APPENDIX 2 \\ JOINT PRESS STATEMENT \\ THE TWENTY - THIRD MEETING OF THE ASEAN \\ ECONOMIC MINISTERS \\ KUALA LUMPUR, MALAYSIA, 7 - 8 OCTOBER 1991}

1 The Twenty - Third Meeting of the ASEAN Economic Ministers (AEM) was held in Kuala Lumpur, Malaysia on $7-8$ October 1991. The Meeting was formally opened by the Right Honorable Dato' Seri Dr. Mahathir Mohamad, Prime Minister of Malaysia and was preceded by a preparatory Meeting of the ASEAN Senior Economic Officials (SEOM) on 4-5 October 1991

2 The Meeting was attended by H.E. Pehin Dato Abdul Rahman Taib, Minister of Industry and Primary Resources of Brunei Darussalam; H.E. Dr. Arifin M. Siregar Minister of Trade of Indonesia; H.E. Mr. Hartarto, Minister of Industry of Indonesia; H.E. Dato' Seri Rafidah Aziz, Minister of International Trade and Industry of Malaysia; H.E. Mr. Chua Jui Meng, Deputy Minister of International Trade and Industry of Malaysia; H.E. Mr. Peter D. Garrucho, Jr., Secretary of Trade and Industry of Philippines; H.E. B.G. (Rtd.) Lee Hsien Loong, Deputy Prime Minister and Minister of Trade and Industry of Singapore; H.E. Mr. Lim Boon Heng, Senior Minister of State for Trade and Industry of Singapore; H.E. Mr. Amaret Sila - On Minister of Commerce of Thailand; H.E. Mr. Virabongsa Ramangkura, Deputy Minister of Finance of Thailand; H.E. Mr. Vira Susangkarakan,Deputy Minister of Industry of Thailand and their respective delegations. H.E. Mr. Rusli Noor, secretary general of ASEAN Secretariat and members of his staff were also present.

3 The Right Honourable Dato' Seri Dr. Mahathir Mohamad in this Keynote Address commented on ASEAN's achievement in economic cooperation against the backdrop of rapid growth of the economy of ASEAN members which have benefited from a free economic and trading environment. The Prime Minister expressed concern over the information of trade blocs in the West and emphasized that in the interest of the world economy, the Uruguay Round should be brought to a successful conclusion. In acknowledging the fact that ASEAN on its own is not strong enough to protect free trade, he stressed the need to work together with the East Asian Economies through the information of the East Asian Economic Group (EAEG) which will be GATT - consistent, compatible with APEC, and not detrimental to ASEAN's cohesiveness. The Prime Minister made it clear that the EAEG should not be a trade bloc and should instead stand for free trade. He welcomed the proposal by the Prime Minister of Thailand for an ASEAN Free Trade Area. He pointed out that the private sector would have to be more efficient and assume a greater role in promoting economic cooperation in order to benefit from the economic liberalization policies being implemented by ASEAN member countries. The Prime Minister expressed concern over the use of environmental issues to burden the ASEAN economies. He pointed out the dangers of using these issues as leverage in trade negotiations. The Prime Minister advocated cooperation between developed and developing countries to solve this problem, rather than resorting to confrontational campaigns. He emphasized the need for ASEAN to speak with one voice. The Prime Minister cautioned that efforts to forge closer ASEAN economic cooperation should be complemented by strengthening ASEAN's own machinery. In this context, he emphasized the need to revamp the ASEAN Secretariat considering its important role in ensuring that various decisions, particularly of an economic nature are made expeditiously and implemented

4 H. E. Dato' Seri Rafidah Aziz, leader of Malaysian Delagation, and H.E.Mr. Peter D. Garrucho, Jr., Leader of the Philippines Delegation were elected Chairman and Vice Chairman of the Twenty - Third Meeting of the AEM respectively.

5 The Ministers reviewed the activities undertaken during the past year to implement the decisions of the Third ASEAN Summit.

6 The Ministers noted the fast - changing economic and political environment within and outside the ASEAN region, which presents new challenges and opportunities. They were aware of the need for ASEAN to adopt timely and effective measures to strengthen its intra and extra - ASEAM 
7 The Ministers held extensive discussions on the new initiatives proposed by ASEAN member countries namely, the Common Effective Preferential Tariffs (CEPT) Arrangement, the "Growth Triangle" concept, the establishment of an ASEAN Free Trade Area (AFTA), the ASEAN treaty of economic cooperation as well as the ongoing efforts to improve the ASEAN Preferential Trading Arrangements (PTA) scheme.

8 The Ministers agreed that the new initiatives embody element which are inter - related and intended to expand trade and investment cooperation among ASEAN member countries. In this regard, the Ministers decided to treat the new initiatives as part and parcel of an integrated package towards the creation of a truly liberalized market.

9 The Ministers, in acknowledging the inter - relationship of the new initiatives, agreed that all member countries should subscribe to the establishment of the ASEAN Free Trade Area (AFTA) simultaneously so as to create within the time frame of 15 years a truly liberalized ASEAN market with the Common Effective Preferential Tariff (CEPT) in the range of 0-5 percent for manufactured products. They also agreed that the AFTA shall be effected mainly through the CEPT scheme, while the improved Preferential Trading Arrangements (PTA) scheme will continue to be applied as a complementary tool.

10 The Ministers agreed that the establishment of AFTA with the applications of CEPT on a sectoral basis within the definite time - frame would serve the interest of all member countries, accommodate the respective national conditions and requirements. Leads to the emergence of ASEAN region as a truly liberalized market, and maintain ASEAN's relevance in the world at large beyond the 1990's

11 The Ministers agreed to a Framework Agreement ti implement the various initiatives for the expansion of ASEAN trade, investment and economic cooperation. They assigned the Senior Officials to work out the form and substance of the Framework Agreement to be signed at the Fourth ASEAN Summit.

12 The Ministers acknowledged that the "Growth Triangle" concept is a sub - regional arrangement which complements the overall ASEAN economic cooperation. They assigned the Senior Officials to work out the form and substance of the Framework Agreement to be signed at to Fourth ASEAN Summit.

13 Recognizing the importance of strengthening the existing ASEAN vehicles, particularly the system of ASEAN dialogue partners, in promoting economic cooperation with third countries and multilateral organizations, the Ministers agreed to convening of East Asian economies and to meet as and when the need arises. They agreed that such a Caucus would:

Expand intra - regional cooperation in East Asia which holds vast potentials to further enhance the dynamism of regional economies and, consequently, contribute significantly to the support and promotion of an open and free global trading system. The initiative would provide the necessary collective approach in areas of mutual concern in international economic fora; and

Not be an institutionalised entity and would not be a trading bloc.

14 The Ministers noted the progress of the APEC process.

15 The Ministers agreed that officials pursue the establishment of consultative mechanisms between ASEAN and other dialogue partners in order to enhance trade and economic cooperation with them.

16 The Ministers also reviewed the progress of the activities of the ASEAN Economic Committees since their last meeting in Bali In October, 1990.

17 The Ministers acknowledged that member countries have liberalized their foreign exchange rules and increasingly used ASEAN currencies as settlement currencies. They also noted the status of the ASEAN - Japan Development Fund (AJDF) and called for member countries to make use of the regional project portion in addition to the utilization of the respective allocations for national projects. The Ministers also agreed that cooperation in the area of capital market development be further developed.

18 Regarding ASEAN cooperation on food, agricultural and forestry, the Ministers approved the new projects proposals submitted by the ASEAN Committee on Food, Agriculture and Forestry (COFAF). They noted the continuing efforts by ASEAN member countries to counter the Anti - Tropical Timber Campaign. 
19 The Ministers endorsed the text of a protocol to amend the revised Basic Agreement on AIJV in which ASEAN agrees, among others, on the extension of at least 90 percent Margin of Preferences (MOP) to AIJV products so as to achieve Common Effective Preferential Tariff (CEPT) of $0-5$ percent, the Common Rate of which is to be agreed upon by participating countries. The Ministers also endorsed the following products in the Approval List of the AIJV products;
Enamel (Indonesia and Malaysia);
Heavy Equipment (Conditional agreement by Indonesia and Malaysia);
Aluminium Hydroxide (Indonesia and Thailand);
Breakfast Cereals (all ASEAN countries);
Soya - based milk, soyex and meat analogue (all ASEAN countries);
6. Chocolate wafers, dragees, bouillon tablets (all ASEAN countries);
Non - dairy creamer (all ASEAN countries);
Soya sauce powder (all ASEAN countries).

20 The Ministers agreed to extend the Brand - to - Brand Complementation scheme to non automotive products.

21 The Ministers endorsed the ASEAN Program of Action in Transportation and Communication, as the basis for future cooperation.

22 The Ministers reviewed the progress of ASEAN trade cooperation with particular emphasis on the improvement of the Preferential trading Arrangement (PTA) Scheme. They took into account the independent studies on the PTA since the Third ASEAN Summit and noted that all member countries would meet the target set by the Third ASEAN Summit. The Ministers also noted that all member countries have confirmed their respective programmes and product lists for 1992

23 The Ministers agreed to the following measures for the improvements to the PTA programme:

To further deepen MOP of existing PTA items;

To further reduce the items in the exclusion lists; and

For all member countries to reduce ASEAN content requirement to 40 percent for the first five years. At the end of the fifth year this would be reviewed with a view of raising it back to the original 50 percent.

24 The Ministers noted that a progress report on the visit ASEAN Year 1992 and the post 1992 tourism initiatives would be presented at the $4^{\text {th }}$ ASEAN Summit.

25 On ASEAN's external relations, the Ministers emphasized that the form and substance of ASEAN's relations with third countries, and international and regional organizations need to be in line with the changing international political and economic environment.

26 The Ministers reaffirmed their strong commitment to a successful conclusion of the Uruguay Round of Multilateral Trade Negotiations (URMTN). They urged the major trading economies to adopt greater flexibility to contribute to the success of the URMTN.

27 The Ministers expressed concern over increasing support and protectionism by industrialized countries for their agricultural sector through farm subsidies. They emphasized the need for ASEAN to project a stronger voice against farm subsidies through joint efforts of member countries and closer consultation with the Cairns Group.

28 The Ministers noted that the Anti - Tropical Timber campaign still went on unabated. They felt that ASEAN should continue cooperation efforts with the develop countries to resolve this problem on the basis of shared responsibility and better understanding.

29 The Ministers expressed their serious concern over the use of environmental issues as a pretext to impose trade restrictive measures on developing countries.

30 The Ministers noted increasing trend of trade restrictive measures in the form of anti dumping and countervailing duties. They agreed that ASEAN should continue to monitor this trend and have close consultation on appropriate steps to counter the trade restrictive measures. 
31 The Ministers noted the Report of the Penal of the Five Eminent Person on "Strengthening the Structure and Mechanism of the ASEAN Machinery with Special Reference to the ASEAN Secretariat". They agreed that any measures adopted should be in accordance with goals and requirements of ASEAN activities.

32 The Ministers expressed their appreciation to the ASEAN - CCI for its recommendations to enhance ASEAN economic cooperation. They urged the ASEAN - CCI to take a more active involvement in existing ASEAN economic activities as well as the new initiatives being proposed.

33 The Ministers were briefed by Singapore on the preparation for Fourth ASEAN Summit which will be held in Singapore in January 1992.

34 The Ministers agreed to hold the Twenty - Fourth AEM Meeting in the Philippines in 1992.

35 The Ministers expressed their most grateful appreciation to the Right Honorable Dato' Seri Dr. Mahathir Mohamad, Prime Minister of Malaysia, for his Keynote Address, setting out the guidance for their deliberation.

36 The delegations of Brunei Darussalam, Indonesia, the Philippines, Singapore and Thailand expressed appreciation to the Government and people of Malaysia for the warm hospitality extended to them and the excellent arrangements made for the meeting.

37 The Meeting was held in the spirit of ASEAN cordiality, solidarity, and a sense of pragmatism.

SOURCE: Law and Practice under the GATT: The Association of Southeast Asian Nations, compiled and edited by Paul Davidson, (New York: Oceana Publications, 1995). 


\section{APPENDIX 3}

\section{FRAMEWORK AGREEMENT ON ENHANCING ASEAN ECONOMIC COOPERATION}

The Sultan of Brunei Darussalam, the President of the Republic of Indonesia, the Prime Minister of Malaysia, the President of the Republic of the Philippines, the Prime Minister of the Republic of Singapore and the Prime Minister of the Kingdom of Thailand:

REAFFIRMING their commitment to the ASEAN Declaration of 8 August 1967, the Declaration of ASEAN Concord of 24 February 1976, the Treaty of Amity and Cooperation in Southeast Asia of 24 February 1976, the 1977 Accord of Kuala Lumpur and the Manila Declaration of 15 December 1987;

DESIRING to enhance intra - ASEAN economic cooperation to sustain the economic growth and development of all Member States which are essential to the stability and prosperity of the region;

REITERATING their commitment to the principles of the General Agreement on Tariffs and Trade (hereinafter referred to as GATT);

RECOGNISING that tariff and non - tariff barriers are impediments to intra - ASEAN trade and investment flows, and that existing commitments to remove these trade barriers could be extensively improved upon;

NOTING the significant unilateral efforts made by Member States in recent years to liberalise trade and promote investments, and the importance of extending such policies to further open up their economies; given the comparative advantages and complementary of their economies;

RECOGNISING that Member States, having different economic interests, could benefit from sub - regional arrangements;

CONSCIOUS of the rapid and pervasive changes in the international political and economic landscape as well as both cohesive and effective performance of intra - ASEAN economic cooperation;

MINDFUL of the need to extend the spirit of friendship and cooperation among Member States to other regional economies, as well as those outside the region which contribute to the overall economic development of Member States;

RECOGNISING further the importance of enhancing other fields of economic cooperation such as in science and technology, agriculture, financial services and tourism;

HAVE AGREED AS FOLLOWS:

Article 1: Principles

9 Member States shall endeavour to strengthen their economic cooperation through an outward looking attitude so that their cooperation contributes to the promotion of global trade liberalisation.

Member States shall abide by the principles of mutual benefit in the implementation of measures or initiative aimed at enhancing ASEAN economic cooperation.

All Member States shall participate in intra - ASEAN economic arrangements. However, in the implementation of these economic arrangements, two or more Member States may proceed first if other Member States are not ready to implement these arrangements.

\section{Article 2: Areas of Cooperation}

\section{A. Cooperation in Trade}

(8) All Member States agree to establish and participate in the ASEAN Free Trade Area (AFTA) within 15 years. A ministerial - level Council will be set up to supervise, coordinate and review the implementation of the AFTA

The Common Effective Preferential Tariff (CEPT) Scheme shall be the main mechanism for the AFTA. For products not covered by the CEPT Scheme, the ASEAN Preferential Trading Arrangements (PTA) or any mechanism to be agreed upon, may be used. 
Member States shall reduce or eliminate non - tariff barriers between and among each other on the import and export of products as specifically agreed upon under existing arrangements arising out of this Agreement.

Member States shall explore further measures on border and non - border areas of cooperation to supplement and complement the liberalisation of trade.

B. Cooperation in Industry, Minerals and Energy

Member States agree to increase investments, industrial linkages and complementarity by adopting new and innovative measures, as well as strengthening existing arrangements in ASEAN.

Member States shall provide flexibility for new forms of industrial cooperation. ASEAN shall strengthen cooperation in the development of the minerals sector

9 Member States shall enhance cooperation in the field of energy, including energy planning, exchange of information, transfer of technology, research and development, manpower training, conservation and efficiency, and the exploration, production and supply of energy resources.

C. Cooperation in Finance and Banking

Member States shall strengthen and develop further ASEAN economic cooperation in the field of capital markets, as well as find new measures to increase cooperation in this area.

Member States shall encourage and facilitate free movement of capital and other financial resources, including further liberalisation of the use of ASEAN currencies in trade and investments, taking into account their respective national laws, monetary controls and development objectives.

D. Cooperation in Food, Agriculture and Forestry

Member States agree to strengthen regional cooperation in the areas of development, production and promotion of agricultural products for ensuring food security and upgrading information exchanges in ASEAN.

Member States agree to enhance technical joint cooperation to better manage, conserve, develop and market forest resources.

E. Cooperation in Transportation and Communications

Member States agree to further enhance regional cooperation for providing safe, efficient and innovative transportation and communications infrastructure network.

Member States shall also continue to improve and develop intra - country postal and telecommunications system to provide cost - effective, high quality and consumer oriented services.

\section{Article 3: Other Areas of Cooperation}

1. Member States agree to increase cooperation in research and development, technology transfer, tourism promotion, human resource development and other economic - related areas. Full account shall also be taken of existing ASEAN arrangements in these areas.

2. Member States, through the appropriate ASEAN bodies, shall regularly consult and exchange views on regional and international developments and trends, and identify ASEAN priorities and challenges.

\section{Article 4: Sub - regional Economic Arrangements}

Member States acknowledge that sub - regional arrangements among themselves, or between ASEAN Member States ad no - ASEAN economies, could complement overall ASEAN economic cooperation. 


\section{Article 5: Extra-ASEAN Economic Cooperation}

To complement and enhance economic cooperation among Member States, and to respond to the rapidly changing external conditions and trends in both the economic and political fields, Member States agree to establish and / or strengthen cooperation with other countries, as well as regional and international organizations and arrangements.

\section{Article 6: Private Sector Participation}

Member States recognise the complementarity of trade and investment opportunities, and therefore encourage, among others, cooperation and exchanges among the ASEAN private sectors and between ASEAN and non - ASEAN private sectors, and the consideration of appropriate policies aimed at promoting greater intra - ASEAN and extra - ASEAN investments and other economic activities.

\section{Article 7: Monitoring Body}

The ASEAN Secretariat shall function as the body responsible for monitoring the progress of any arrangements arising from this Agreement. Member States shall cooperate with the ASEAN Secretariat in the performance of its duties.

\section{Article 8: Review of Progress}

The ASEAN Economic Ministers' Meeting and its subsidiary bodies shall review the progress of implementation and cooperation of the elements contained in this Agreement.

\section{Article 9: Settlement of Disputes}

Any differences between the Member States concerning the interpretation or application of this Agreement or any arrangements arising there from shall, as far as possible, be settled amicably between the parties. Whenever necessary, and appropriate body shall be designated for the settlement of disputes.

\section{Article 10: Supplementary Agreements or Arrangements}

Appropriate ASEAN economic agreements or arrangements, arising from this Agreement, shall form an integral part of this Agreement.

\section{Article 11: Other Arrangements}

A. This Agreement or any action taken under it shall not affect the rights and obligations of the Member States under any existing agreements to which they are parties.

B. Nothing in this Agreement shall affect the power of Member States to enter into other agreements not contrary to the terms and objectives of this Agreement.

\section{Article 12: General Exceptions}

Nothing in this Agreement shall prevent any Member States from taking action and adopting measures which it considers necessary for the protection of its national security, the protection of public morals, the protection of human, animal or plant life and health, and the protection of articles of artistic, historic and archaeological value.

\section{Article 13: Amendments}

All Articles of this Agreement may be modifies through amendments to this Agreement agreed upon by all the Member States. All amendments shall become effective upon acceptance by all Member States. 
Article 14: Entry into Force

This agreement shall be effective upon signing.

\section{Article 15: Final Provision}

This Agreement shall be deposited with the Secretary General of the ASEAN Secretariat who shall promptly furnish a certified copy thereof to each Member States.

IN WITNESS WHEREOF, the undersigned have signed this Framework Agreement on Enhancing ASEAN Economic Cooperation.

DONE in Singapore on the $28^{\text {th }}$ day of January, 1992 in a single copy in English Language.

Source: ASEAN Economic Bulletin, Vol. 8, No. 3, March 1992, pp. 381 - 385 
APPENDIX 4

Table A.1: Trade Balance of Selected ASEAN Countries

\begin{tabular}{|c|c|c|c|c|c|}
\hline & & 1980 & 1985 & 1990 & 1992 \\
\hline \multirow{3}{*}{ Brunei } & Imports & 844,40 & 689.50 & $1,644.90$ & $2,173.00$ \\
\hline & Exports & $6,760.90$ & $3,340.60$ & $2,166.80$ & $2,252.80$ \\
\hline & Balance & $5,916.50$ & $2,651.10$ & 521.90 & 79.80 \\
\hline \multirow{3}{*}{ Indonesia } & Imports & $15,967.30$ & $11,697.40$ & $21,008.80$ & $26,302.20$ \\
\hline & Exports & $32,280.80$ & $21,171.40$ & $24,512.60$ & $32,241.70$ \\
\hline & Balance & $16,313.50$ & $9,474.00$ & $3,503.80$ & $5,939.60$ \\
\hline \multirow{3}{*}{ Malaysia } & Imports & $15,943.70$ & $14,003,90$ & $27,849.40$ & $38,041.20$ \\
\hline & Exports & $19,095.30$ & $17,541.00$ & $28,088.00$ & $38,786.30$ \\
\hline & Balance & $3,151,60$ & 3.537 .10 & 238.70 & 745.10 \\
\hline \multirow{3}{*}{ Philippines } & Imports & $12,221.70$ & $6,092.20$ & $12,404.40$ & $15,377.60$ \\
\hline & Exports & $8,526.60$ & $5,252.70$ & $7,800.90$ & $9,788.70$ \\
\hline & Balance & $-3,695.20$ & -839.50 & $-4,603.50$ & $-5,588.90$ \\
\hline \multirow{3}{*}{ Singapore } & Imports & $35,380.90$ & $29,869.10$ & $58,194.40$ & $72,533,40$ \\
\hline & Exports & $28,550.20$ & $25,969.90$ & $50,364.70$ & $47,261.20$ \\
\hline & Balance & $-6,380.70$ & $3,899.10$ & $-7,829.70$ & $-25,272,20$ \\
\hline \multirow{3}{*}{ Thailand } & Imports & $13,573.90$ & $10,541.30$ & $31,895.00$ & $38,764.50$ \\
\hline & Exports & $9,579.00$ & $8,108.90$ & $22,027.10$ & $30,938.80$ \\
\hline & Balance & $-3,994.80$ & $-2,432.40$ & $9,868.00$ & $-7,825.70$ \\
\hline
\end{tabular}

SOURCE: Boutin, J.D. Kenneth, "Statistical Appendix", in Acharya, Amitav and Richard Stubbs, ed., New Challenges for ASEAN: Emerging Policy Issues, (Vancouver; University of British Columbia Press, 1995), p. 207 


\section{APPENDIX 5}

Table A.2:Intra - ASEAN Trade: Amount of Trade with Other ASEAN States and Percentage of Total Trade

\begin{tabular}{|c|c|c|c|c|c|c|c|c|}
\hline & \multicolumn{2}{|c|}{1980} & \multicolumn{2}{|c|}{1985} & \multicolumn{2}{|c|}{1990} & \multicolumn{2}{|c|}{1992} \\
\hline & Imports & Exports & Imports & Exports & Imports & Exports & Imports & Exports \\
\hline \multirow[t]{2}{*}{ Brunei } & 220.80 & 861.50 & 223.10 & 695,30 & 701.60 & 366.80 & 839.70 & 454.70 \\
\hline & $26.10 \%$ & $12.70 \%$ & $32.40 \%$ & $20.80 \%$ & $42.70 \%$ & $16.90 \%$ & $38.60 \%$ & $20.20 \%$ \\
\hline \multirow[t]{2}{*}{ Indonesia } & $1,989.00$ & $4,066.60$ & $1,096.20$ & $2,257.50$ & $1,730.00$ & 2,401:10 & $2,680.10$ & $3,753.00$ \\
\hline & $12: 50 \%$ & $12.60 \%$ & $9.40 \%$ & $10.70 \%$ & $8.20 \%$ & $9.80 \%$ & $10.20 \%$ & $11.60 \%$ \\
\hline \multirow[t]{2}{*}{ Malaysia } & $2,613.90$ & $4,306.70$ & $3,134.00$ & $4,534.40$ & $5,234.80$ & $8,217.40$ & $7,756.60$ & $11,446.60$ \\
\hline & $16.40 \%$ & $22.60 \%$ & $22.40 \%$ & $25.90 \%$ & $18.80 \%$ & $29.30 \%$ & $20.40 \%$ & $29.50 \%$ \\
\hline \multirow[t]{2}{*}{ Philippines } & 823.70 & 560.40 & 885.00 & 589.10 & $1,200.80$ & 558.30 & $1,409.20$ & 580.50 \\
\hline & $6.70 \%$ & $6.60 \%$ & $14.50 \%$ & $11.40 \%$ & $9.70 \%$ & $7.20 \%$ & $9.20 \%$ & $6.00 \%$ \\
\hline \multirow[t]{2}{*}{ Singapore } & $9,659.60$ & $7,717.70$ & $7,227.90$ & $6,643.90$ & $11,716.40$ & $12,275.80$ & $17,832.20$ & $11,014,00$ \\
\hline & $24.80 \%$ & $22.80 \%$ & $22.80 \%$ & $24.70 \%$ & $19.50 \%$ & $23.90 \%$ & $23.40 \%$ & $21.50 \%$ \\
\hline \multirow[t]{2}{*}{ Thailand } & $1,627.50$ & $1,567.90$ & $1,920.60$ & $1,173.90$ & $3,904.70$ & $2,504.30$ & $4,951.20$ & $3,932.00$ \\
\hline & $12.00 \%$ & $18.20 \%$ & $18.20 \%$ & $14.50 \%$ & $12.20 \%$ & $11.40 \%$ & $12.80 \%$ & $12.70 \%$ \\
\hline
\end{tabular}

SOURCE: Boutin, J. D. Kenneth, "Statistical Appendix", in Acharya, Amitav and Richard Stubbs, ed., New Challenges for ASEAN:

Emerging Policy Issues, (Vancouver: University of British Columbia Press, 1995), p. 208. 


\section{APPENDIX 6 : Initial Research Proposal}

\section{INTRA-ASEAN ECONOMIC COOPERATION.}

\section{STATEMENT OF RESEARCH OBJECTIVE}

The Association of Southeast Asian Nations (ASEAN) was formed in 1967 with the main objective of facilitating economic and cultural cooperation among the member states. ASEAN's original members were Indonesia, Malaysia, the Philippines, Singapore and Thailand. It was later joined by Brunei in 1984 and Vietnam in 1995. the motivating factor for the establishment of ASEAN was twofold - to foster economic and cultural cooperation; and to maintain security in the Southeast Asian region.

As a regional organization, ASEAN has, since 1967, attempted to intensify its economic cooperation between the member states. Among its various attempts were to forget greater interdependence through increasing intra - regional trade and lifting tariff barriers. Projects such as the 1982 ASEAN Industrial Joint Venture (AIJV), a joint investment project among the private sectors; the 1980 ASEAN Industrial Projects (AIPs), as a resource - pooling and market - sharing initiative; and the Preferential Trading Arrangements (PTAs) are examples of ways in which ASEAN has sought to increase economic cooperation.

ASEAN's economic cooperation entered a new phase in 1991, following the ASEAN Economic Ministers (AEM) Meeting in Kuala Lumpur. The meeting agreed upon the implementation of a new trading arrangement - the Common Effective Preferential Treatment (CEPT), the creation of an ASEAN Free Trade Area (AFTA) and the adoption of an East Asian Economic Caucus (EAEC) as an ASEAN project. The agreement achieved in this meeting has changed the nature of economic cooperation in the region - from a loose cooperation to a significant degree of economic integration in the region. Therefore, this research seeks to examine the transformation from ASEAN's agreement of economic cooperation to the fostering of regional economic integration. 


\section{STATEMENT OF RESEARCH METHOD}

Since it is almost impossible to identify a single factor contributing to the trends of integration, it can be argued that this process stems out of two inter - related factors, namely; a gradual transformation approach (institution - building), and as a reaction to the global economic trends toward economic grouping. This paper will also attempt at understanding the various issues in ASEAN economic integration and its position in the wider economic transformation in the Asia-Pacific region,

The nature of this research will be mostly descriptive. However, it will also deal with the theoretical aspects of regionalism and economic integration. Moreover, it will analyse the current issues in the ASEAN economic relations in the light of contemporary trends in economic regionalism. This research will be divided into four main components:

1. historical background and theoretical perspectives

2. economic cooperation since 1976

3. economic integration since 1991

4. analysis of ASEAN's efforts and achievements in the economic field.

\section{STATEMENT OF PRINCIPAL SOURCES TO BE USED}

In terms of sources, it will depend on existing literature on ASEAN's economic and foreign relations. This research will also consider current journals and newspaper articles on perspectives of ASEAN economic integration. Furthermore, it will also examine the official documents of various ASEAN Economic Ministers Meeting and ASEAN Summit. 


\section{REFERENCES}

Lee Kuan Yew, From Third World to First: The Singapore Story 1965-2000, (HarperCollinsPublishers, 2000).

Damien Kingsbury, South-East Asia: A Political Profile, (UK: Oxford University Press, 2001).

David F. Pulis, ASEAN: Organizing for Economic Cooperation in Southeast Asia, (USA: New York: St. Martin's Press, 1989).

Acharya, Amitav and Richard Stubbs, ed., New Challenges for ASEAN: Emerging Policy Issues, (Vancouver: University of British Columbia Press, 1995).

Blomqvist, Hans C., "ASEAN as a Model for Third World Cooperation?", in ASEAN Economic Bulletin, Vol. 10, No. 1, July 1993.

Broinowski, Alison, ed., ASEAN into the 1990s, (New York: St. Martin's Press, 1990).

Business International Asia Research Report, ASEAN: Challenges of an Integrating Market, (Hong Kong: Business International Asia / Pacific Ltd., 1979).

Crouch, Harold, Domestic Political Structures and Regional Economic Cooperation, (Singapore: Institute of Southeast Asia Studies, 1984).

Garnaut, Ross and Peter Drysdale, ed., Asia Pacific Regionalism: Readings in International Economic Relations, (New South Wales: HarperEducational, 1994).

Harris, Stuart, "The Economic Aspects of Security in the Asia / Pacific Region", in Joumal of Strategic Studies, 1995 Special Issue, (London: Frank Cass, 1995).

International Monetary Fund, World Economic Outlook: A Survey by the Staff of IMF, (Washington D.C.: International Monetary Fund, 1996).

Langhammer, Rolf J., "ASEAN Economic Cooperation: A Stack - Taking From a Political Economy Point of View", in ASEAN Economic Bulletin, Vol. 8, No. 2, November 1991.

Law and Practice under the GATT: The Association of Southeast Asian Nations, Paul Davidson, (New York : Aceana Publications, 1995).

Law and Practice under the GATT: ASEAN and APEC compiled and edited by Paul Davidson, (New York : Aceana Publications, 1996).

Naya, Seiji and Pearl Imada, ed., AFTA: The Way Ahead, (Singapore: Institute of Southeast Asian Studies, 1992).

Michael G. Plummer, "ASEAN Economic Cooperation in the New International Economic Environment", in ASEAN Economic Bulletin, Vol. 7, No. 3, March 1991.

Pangestu, Mari, Hadi Soesastro and Mubariq Ahmad, "A New Look at Intra - ASEAN Economic Cooperation", in ASEAN Economic Bulletin, Vol. 8, No. 3, March 1992.

Rajendran, M., ASEAN's Foreign Relations: The Shift to Collective Action, (Kuala Lumpur: Arenabuku, 1985).

Ravehill, John, "Economic Cooperation in Southeast Asia: Changing Incentives", in Asian Survey, Vol. 35, No. 9, September, 1995.

Robson, Peter, The Economics of International Integration, (London: Allen and Unwin, 1980).

Rudner, Martin, "APEC: The Challenges of Asia Pacific Economic Cooperation", in Modern Asian Studies, Vol. 29, Part 2, May 1995.

Sandhu, K.S., Sharon Siddique, et. al., The ASEAN Reader, (Singapore: Institute of Southeast Asian Studies, 1992)

Shee Pooh Kim, "A Decade of ASEAN: 1967 - 1977", in Asian Survey, Vol. 17, No. 8, August 1977.

Suriyamongkol, Marjorie L., Politics of ASEAN Economic Cooperation, (Singapore: Oxford University Press, 1988). 
Newspapers

Bangkok Post, November 23, 1991.

Business Times (Malaysia), November 23, 1995.

The Xinhua General Overseas News Service, October 08, 1991.

\section{Magazines}

Far Eastern Economic Review, February 06, 1992, April 06, 1996.

Asiaweek April 06, 1996.

Internet

www.aseansec.org

wuw. aseanreview.com

www.asiasociety.org

www.aseantradefair:com 